January 2003 • NREL/TP-550-31977

\title{
Guidelines for the Economic Evaluation of Building- Integrated Photovoltaic Power Systems
}

P. Eiffert

Imaginlt LLC

International Energy Agency PVPS Task 7: Photovoltaic Power Systems in the Built Environment

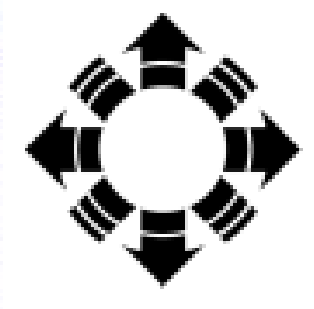

\section{NPEI}

National Renewable Energy Laboratory

1617 Cole Boulevard

Golden, Colorado 80401-3393

NREL is a U.S. Department of Energy Laboratory

Operated by Midwest Research Institute $\bullet$ Battelle $\bullet$ Bechtel

Contract No. DE-AC36-99-G010337 


\section{Guidelines for the Economic Evaluation of Building- Integrated Photovoltaic Power Systems}

P. Eiffert

ImaginIt LLC

International Energy Agency PVPS Task 7: Photovoltaic Power Systems in the Built Environment

Prepared under Task No. PVP28201

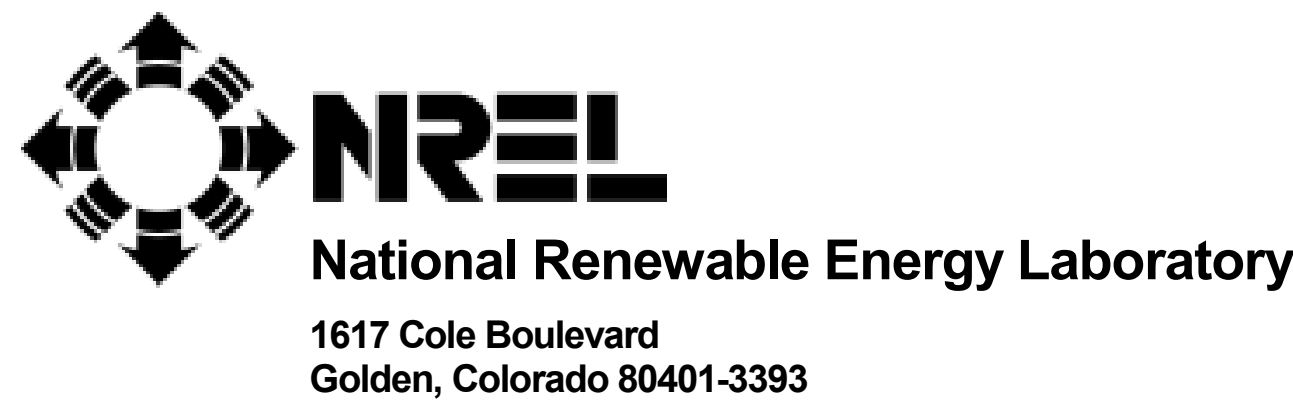

NREL is a U.S. Department of Energy Laboratory

Operated by Midwest Research Institute $\bullet$ Battelle $\bullet$ Bechtel

Contract No. DE-AC36-99-G010337 


\section{NOTICE}

This report was prepared as an account of work sponsored by an agency of the United States government. Neither the United States government nor any agency thereof, nor any of their employees, makes any warranty, express or implied, or assumes any legal liability or responsibility for the accuracy, completeness, or usefulness of any information, apparatus, product, or process disclosed, or represents that its use would not infringe privately owned rights. Reference herein to any specific commercial product, process, or service by trade name, trademark, manufacturer, or otherwise does not necessarily constitute or imply its endorsement, recommendation, or favoring by the United States government or any agency thereof. The views and opinions of authors expressed herein do not necessarily state or reflect those of the United States government or any agency thereof.

Available electronically at http://www.osti.gov/bridge

Available for a processing fee to U.S. Department of Energy

and its contractors, in paper, from:

U.S. Department of Energy

Office of Scientific and Technical Information

P.O. Box 62

Oak Ridge, TN 37831-0062

phone: 865.576.8401

fax: 865.576.5728

email: reports@adonis.osti.gov

Available for sale to the public, in paper, from:

U.S. Department of Commerce

National Technical Information Service

5285 Port Royal Road

Springfield, VA 22161

phone: 800.553.6847

fax: 703.605.6900

email: orders@ntis.fedworld.gov

online ordering: http://www.ntis.gov/ordering.htm 


\section{Foreword}

The International Energy Agency (IEA), founded in November 1974, is an autonomous body within the framework of the Organisation for Economic Co-operation and Development (OECD), which carries out a comprehensive program of energy cooperation among its 23 member countries. The European Commission also participates in this work.

The IEA Photovoltaic Power Systems (PVPS) Programme is a collaborative R\&D agreement. Since 1993, its participants have conducted a variety of joint projects concerned with converting photovoltaic (PV) solar energy into electricity. An executive committee composed of one representative from each participating country heads the program. Operating agents manage individual research projects (Tasks), and activities are underway in 7 Tasks.

The 21 members of the IEA PVPS Programme are Australia, Austria, Canada, Denmark, European Commission, Finland, France, Germany, Israel, Italy, Japan, Korea, Mexico, the Netherlands, Norway, Portugal, Spain, Sweden, Switzerland, United Kingdom, and the United States.

Task 7 focuses on building-integrated PV, linking developments in IEA countries. Its overall objective is to enhance the economic viability and architectural and technical quality of PV power systems in the built environment and to assess and remove nontechnical barriers for their introduction as energy-significant options. Task 7 began in January 1997, building on previous IEA collaborative actions (Task 16 of the Solar Heating and Cooling Program).

Task 7 focuses primarily on integrating PV into the architectural designs of roofs and facades for all types of buildings and other structures (such as noise barriers) in the built environment. Task 7 motivates the collaboration among urban planners, architects, building engineers, PV system specialists, utility specialists, the PV and building industry, and other professionals involved in PV.

More information on task activities and results is available at www.task7.org and www.ieapvps.org.

This report was prepared under the supervision of PVPS Task 7 by Patrina Eiffert, Ph.D., director of ImaginIt LLC USA, in cooperation with Australia, Austria, Canada, Switzerland, Denmark, Germany, Finland, Italy, Japan, the Netherlands, Spain, Sweden, Great Britain, and the United States, and approved by the PVPS Programme Executive Committee. The report expresses, as nearly as possible, an international consensus of the opinions on the subject. 


\section{Acknowledgments}

Funding for this project was provided by Photovoltaics for Buildings within the National Center for Photovoltaics (NCPV) at the National Renewable Energy Laboratory (NREL). Support for the NCPV is provided by the U.S. Department of Energy (DOE) Office of Power Technologies. The project was also funded by DOE's Federal Energy Management Program (FEMP).

Much of this work is based on guiding principles already established by the National Institute for Standards and Technology (NIST) within the U.S. Department of Commerce's Office of Applied Economics. NIST pioneered the development of building life cycle cost analysis relative to energy use and conservation in buildings. The authors wish to acknowledge the valuable contributions of Rosalie Ruegg from NIST.

\section{Executive Summary}

This report identifies the economic parameters of building-integrated PV (BIPV) systems. The guidelines are structured in three major parts: the investment analysis (methods and ownership issues), benefits, and costs. Measurement and verification are also discussed briefly.

The outline and evaluation of investment analysis methods showed their effectiveness for BIPV systems. All investment methods can be used to evaluate BIPV economics (in relation to other techniques). However, for designing and sizing BIPV systems, either net present value or life cycle cost is recommended because BIPV tends to have increased net benefits and leads to reduced life cycle costs.

The criteria for cost effectiveness depend on the investment decision maker. The most likely decision maker is the long-term owner-occupant, who is best positioned to reap the benefits of a capital-intensive BIPV system with low operating costs.

The advantages of BIPV systems include multiple (building) functions, electricity benefits, gridsupport benefits, control of load growth by utilities (institutionalized by utility and national incentives and programs), demand savings, power quality and reliability, promotional and educational benefits, environmental benefits, shading and thermal benefits, and security. Each topic is addressed, and international examples are given for most.

The costs of BIPV systems depend on the system technology, utility interconnection costs, labor and installation costs, associated costs for building permits, maintenance costs, costs for replacement and repair, and the salvage costs (or value). Each topic is addressed, and international examples are given for most.

The international BIPV market is diverse and rapidly developing, so no general quantitative data could be presented of its costs and benefits. However, this report reflects an extensive list of valuable data addressing all possible economic factors relevant for an economic analysis. The report can be used as a guideline to perform an economic analysis of BIPV systems. 


\section{Table of Contents}

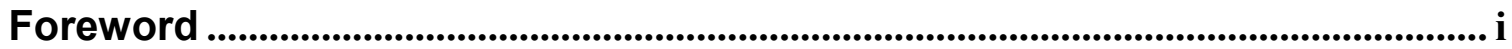

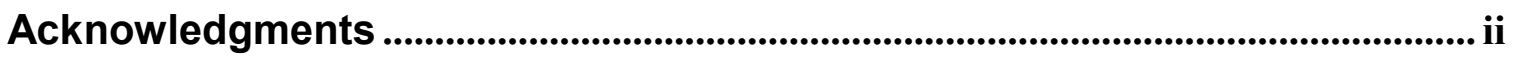

Executive Summary ........................................................................................... ii

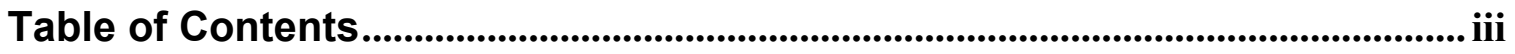

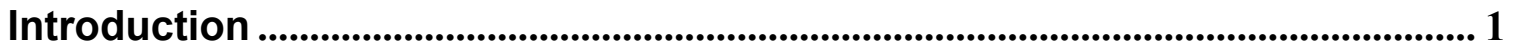

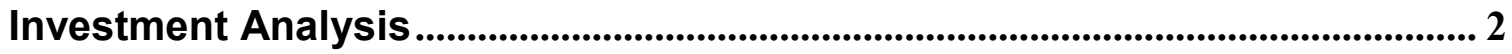

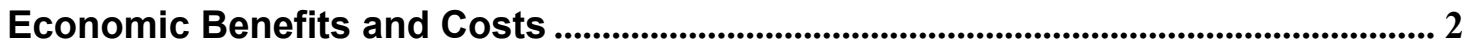

Economic Methods of Investment Analysis............................................................. 3

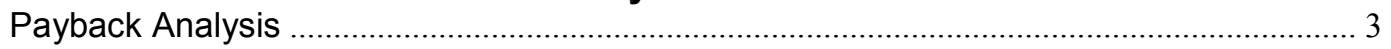

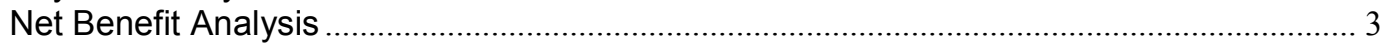

Savings-to-Investment Ratio ............................................................................................ 3

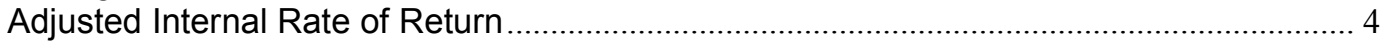

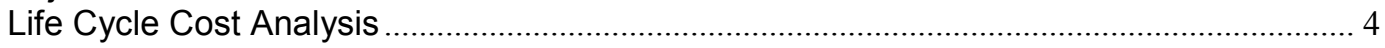

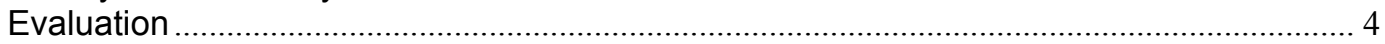

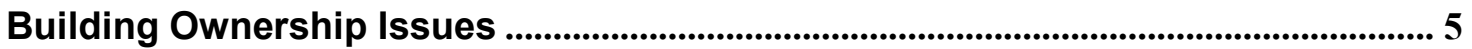

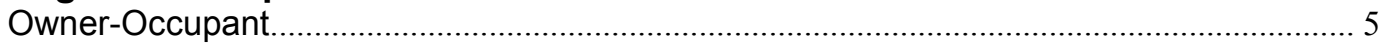

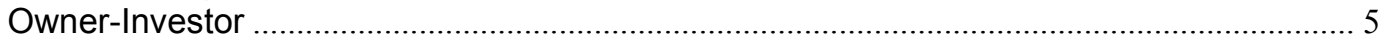

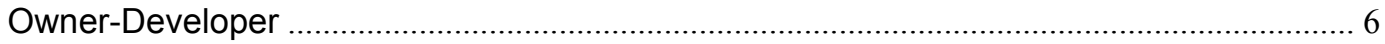

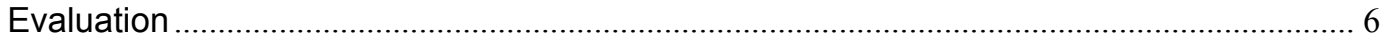

Benefits of Building-Integrated Photovoltaic Systems .................................... 7

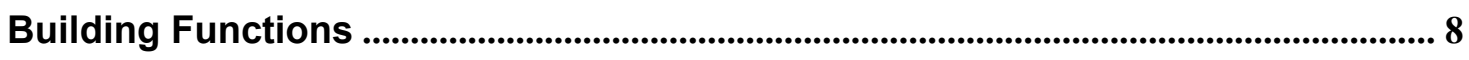

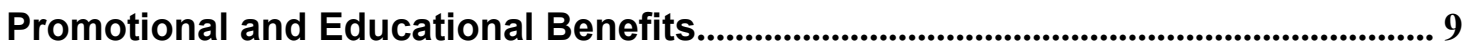

Thermal Benefits ................................................................................................................................... 9

Electricity Benefits..................................................................................................................... 11

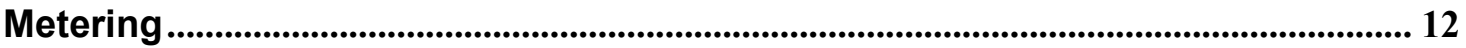

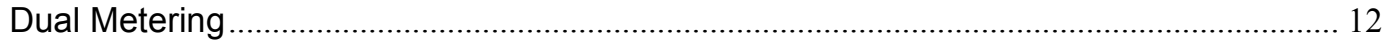

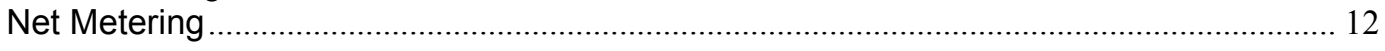

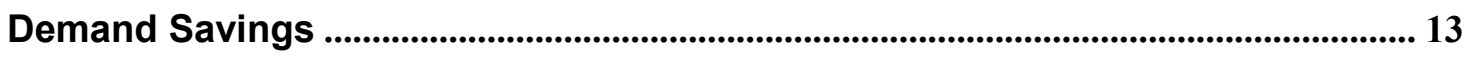

Power Quality and Reliability ........................................................................................................ 14

Photovoltaics Benefits to Grid Support .................................................................................... 14

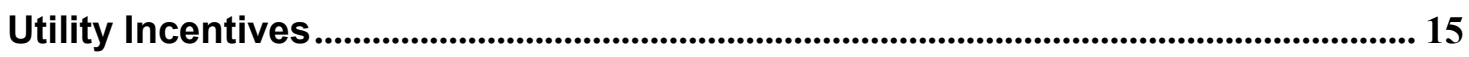

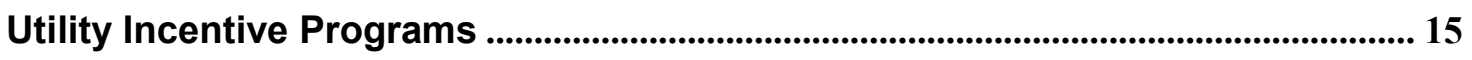

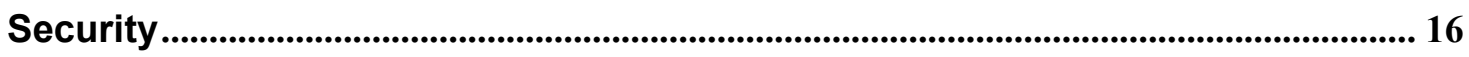

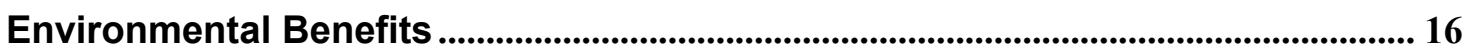

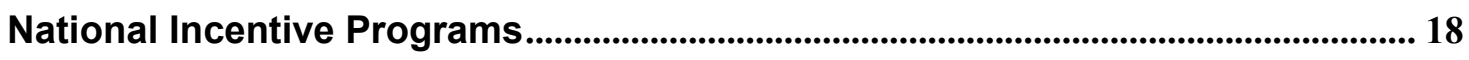

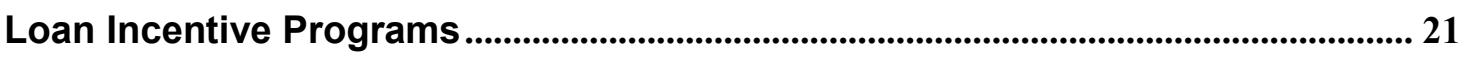




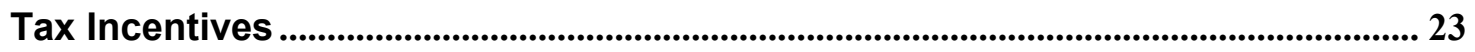

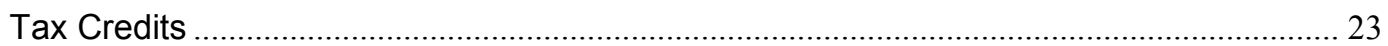

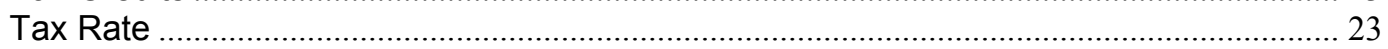

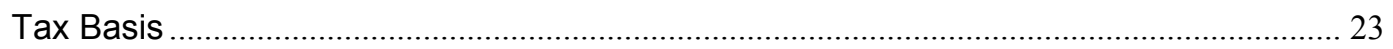

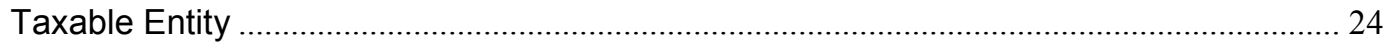

Energy Tax ................................................................................................................................... 24

Costs of BIPV Systems ............................................................................................... 25

Building-Integrated Photovoltaic System Costs........................................................... 25

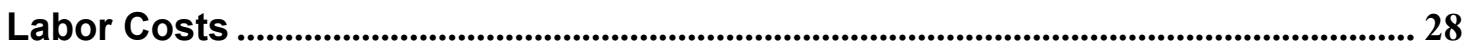

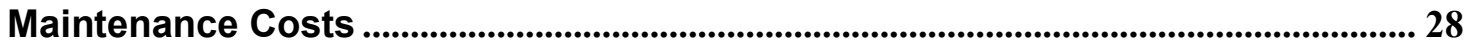

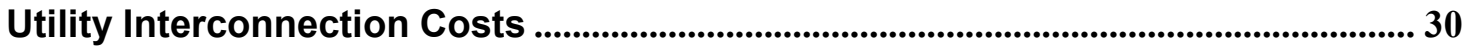

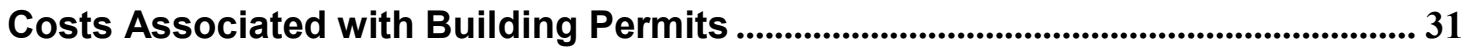

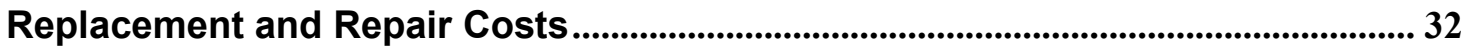

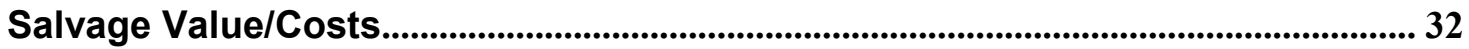

Measurement and Verification for BIPV................................................................. 33

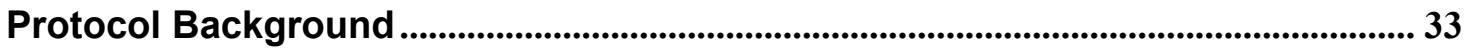

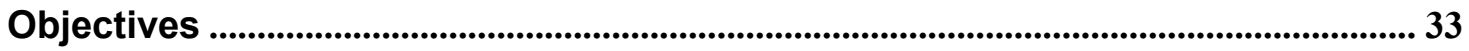

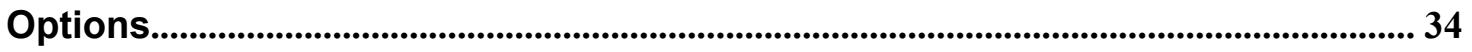

Importance of Measurement and Verification .................................................................. 34

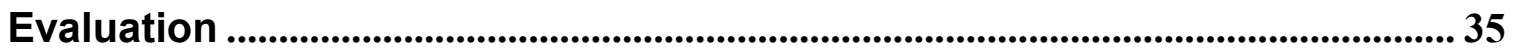

References \& Bibliography ......................................................................................... 36

Appendix A: Acronyms and Abbreviations ................................................................ 40

Appendix B: Glossary....................................................................................................... 41

Appendix C: Methods of Assessing Capital Budget Decisions ......................... 43 


\section{Introduction}

Utility companies usually provide electrical service for buildings. Electricity industry restructuring and successful $\mathrm{R} \& \mathrm{D}$ for building-integrated photovoltaics (BIPV) has raised a question for building owners to consider: Is photovoltaics (PV) for individual buildings worth the investment?

A BIPV system operates as a multifunctional building construction material; it generates energy and is part of the building envelope. This report identifies the economic parameters of BIPV systems.

The Investment Analysis section identifies methods of assessing the economic performance of BIPV systems. A major barrier to analyzing renewable energy systems is assembling and presenting the technical and financial data in forms that will help an investor determine whether a BIPV system would make economic sense. Economic methods of investment analysis, such as payback period, net benefit analysis, savings-to-investment ratio (SIR), adjusted internal rate of return (AIRR), life cycle cost (LCC) analysis, and sensitivity analysis based on building ownership are presented. The owner-occupant, owner-investor, and owner-developer are considered.

The Benefits of Building-Integrated Photovoltaic Systems section describes the benefits that can affect the decision-making process. These benefits derive from energy cost savings, revenue or credits from the sale of power, enhanced power quality and reliability, reduced construction costs, reduced environmental emissions, increased rents, tax credits, rebates, and other incentives. Some benefits can be identified, evaluated in monetary terms, and entered into the calculation of economic performance. Others may be difficult to quantify and are considered qualitative.

The Costs of BIPV Systems section characterizes the relative costs for the building owner. Limited objective published data are available on BIPV system costs. A preliminary survey conducted in this study indicates that manufacturer-marketing representatives and system integrators offer widely varying cost estimates. Consequently, three to five vendor bids should be collected and reviewed before an investment decision is made. There can also be hidden or unexpected costs, which will be examined in this section.

The Measurement and Verification for BIPV section specifies measurement and verification $(\mathrm{M} \& \mathrm{~V})$ protocols for BIPV systems. Prescribing an internationally accepted guideline for $\mathrm{M} \& \mathrm{~V}$ can ensure that generation and savings requirements in BIPV systems will be accurately, consistently, and objectively determined.

This report presents financial data in U.S. dollars (USD). For conversion from Euro to USD, a conversion rate of $1 \mathrm{USD}=0.9105$ Euro was used. 


\section{Investment Analysis}

This section identifies methods of investment analysis and explains how they may be applied to the assessment of BIPV systems. A major barrier to analyzing renewable energy systems is assembling and presenting the technical and financial data in ways that will help an investor decide whether a BIPV system would make economic sense. Economic methods of investment analysis, such as payback period, net benefit analysis, adjusted internal rate of return (AIRR), and life cycle cost (LCC) analysis can be used to evaluate BIPV systems from the standpoint of the owner-occupant, owner-investor, and owner-developer.

In each economic method of analysis, the discount rate plays a major role in determining the uncertainties of alternative costs. Numerous papers have been written on this issue, so it is not discussed here. The economic value of the PV power generated-the determination of the annual revenues of the PV system-is addressed in more detail in The Cost of BIPV Systems section.

\section{Economic Benefits and Costs}

Most architects use some form of quantitative analysis such as net benefit analysis, length of payback period, or internal rate of return (IRR) as a financial criterion to evaluate a building investment. However, according to a survey of American architects, there are a variety of barriers to the widespread investment in BIPV systems. These architects were surveyed at a one-day workshop titled "Building-Integrated Photovoltaics for Design Professionals," which was sponsored by the National Renewable Energy Laboratory (NREL) and the American Institute of Architects (Wenger and Eiffert 1996). Many respondents indicated that a major barrier to analyzing renewable energy systems is assembling and presenting the technical and financial data to help a client determine whether a BIPV system would make economic sense.

Investment evaluations of energy systems generally include an assessment of the projected benefits compared to the estimated costs of the system. The direct financial benefit of a BIPV system is primarily the value of energy generated. These benefits and the direct economic costs of a BIPV may be viewed as:

\section{Projected Benefits $=$ Value of Electricity Generated Estimated Costs $=$ Capital Costs + Periodic Costs + Replacement Costs}

Quantitative analysis facilitates ranking and choosing among investment alternatives and appears to be straightforward. However, numerous factors influence comparative evaluations. A building owner's economic expectations about future interest rates, inflation, and fuel costs directly affect investment decisions, as can utility interface requirements, environmental regulations, and tax incentives.

When PV technology is adapted and used as a building component, as exemplified in BIPV, its economic costs and benefits may be shared between the occupant and the utility company. For a building owner, the added costs of installing and operating a system to generate electricity may be offset by the avoided costs of purchasing electricity, or by selling surplus electricity to the utility company.

Consequently, guidelines to identify the economic value of a BIPV system can be used to help establish rate precedents and calculate an equitable rate structure for taking electricity from or supplying it to the electricity grid. This can be assessed along with the architectural value and 
performance expectations of PV as a building component. Then the value of a BIPV system can also be weighed against the indirect economic benefits or qualitative advantages and disadvantages associated with image, public perception, and visual and environmental impact.

\section{Economic Methods of Investment Analysis}

Five relevant economic methods of financial analysis that are often used for making building investment decisions are payback analysis, net benefit analysis, SIR, AIRR, and LCC analysis. This study will assess the usefulness of these methods in evaluating the economics of BIPV.

\section{Payback Analysis}

The payback period is the minimum time it takes to recover investment costs. The payback period for an energy system is calculated as the total investment cost divided by the first year's revenues from energy saved, displaced, or produced. In payback analysis, the unit of measurement is the number of years to "pay back" the investment cost. Projects with short payback periods are perceived to have lower risks. Simple payback analysis takes into account only initial costs and energy savings at present cost. This method omits several significant cost factors, including the cost escalation rate and the cost of capital. Thus, simple payback analysis can overestimate the actual payback period and, consequently, the length of time to recoup the investment.

The two main variations are payback after taxes and discounted payback. Payback after taxes includes and evaluates marginal tax rates and depreciation schedules. In the discounted payback method, future years' revenues are considered to have less value than current revenues. Discounted payback is the time between the point of initial investment and the point at which accumulated savings (net of the accumulated costs) are sufficient to offset the initial investment costs. Costs and savings are adjusted to account for the changing value of money over time.

For investors who seek rapid return of investment funds, the investment becomes more attractive as the payback period decreases. However, a shorter payback period does not necessarily indicate the most economically efficient investment. An investment with a longer payback period may be more profitable than one with a shorter payback period if it continues to yield savings. The payback is essentially a break-even measure. Payback can be used to determine the minimum time a system must last to recover the investment costs.

The payback method is often used as a rough guide to cost effectiveness. If the payback period is significantly less than the expected system life, the project is likely to be considered cost effective.

\section{Net Benefit Analysis}

Net benefit analysis can be used to express the net difference between the benefits and costs of one energy system relative to an alternative in present or annual value dollars. Net benefits, also called net present values (NPVs), represent the difference between the present value of benefits (revenue or savings) and the present value of costs of the alternative. A system is cost effective if the net saving or net benefit is positive.

\section{Savings-to-Investment Ratio}

The SIR can be used to compare savings to costs of one energy system relative to an alternative energy system. For positive net savings, the SIR must be greater than one. The higher the ratio, the greater the savings realized relative to the investment. 


\section{Adjusted Internal Rate of Return}

The AIRR is a discounted cash flow technique that measures the annual yield from a project, taking into account reinvestment of interim receipts at a specified rate. With this methodology, estimating the cost effectiveness of a project involves comparisons of the calculated AIRR of a project to the investor's minimum acceptable rate of return (MARR). The project is cost effective if the AIRR is greater than the MARR.

The AIRR is calculated by taking the $\mathrm{n}^{\text {th }}$ root of the ratio of the terminal value (TV) of all cash flows (except investment costs) to the present value of investment costs (PVI) and then subtracting one [(TV/PVI)1/n-1]. The AIRR may be contrasted with the IRR, which computes the yield on original investment and is calculated by a trial-and-error process that involves selecting compound interest rates and discounting the cash flows until a rate is found for which the net value of the investment is zero.

\section{Life Cycle Cost Analysis}

In LCC analysis, all relevant present and future costs (less any positive cash flows) associated with an energy system are summed in present or annual value during a given study period (e.g., the life of the system). These costs include, but are not limited to, energy, acquisition, installation, operations and maintenance (O\&M), repair, replacement (less salvage value), inflation, and discount rate for the life of the investment (opportunity cost of money invested). The unit of measurement is present value or annual value dollars. A comparison between the LCC of the energy system to an alternative determines whether it is cost effective. If the LCC is lower than that for the base case and in other aspects is equal, and the project meets the investor's objectives and budget constraints, it is considered cost effective and the preferred investment (Reugg and Marshall 1990).

Various tools have been developed to calculate and compare investments, such as The Building Life Cycle Costs (BLCC) software program developed during the 1980s by the U.S. Department of Commerce (www.nist.gov, National Technical Information Service Order Number PB96: 199229). This program is designed to evaluate and compare the cost effectiveness of building energy conservation components and systems by quantifying all project-related costs. The lowest LCC of the measured energy options is regarded as the most cost effective. The BLCC software provides the payback analysis, SIR, AIRR, NPV, and LCC of a BIPV system so that it can be compared to other energy measures.

\section{Evaluation}

A building owner or operator may ask whether a particular BIPV system is cost effective for a specific building. For example, a building owner with a limited budget to retrofit a building for energy efficiency is given ten alternative modifications (including the BIPV system) that together equal a total of four times the planned budget. The problem is determining which combination of alternatives should be selected to optimize the investment.

The methods of investment analysis presented can be helpful in making a variety of investment decisions, but they are not equally well suited for all types of decisions. All the methods can, in most cases, be used to determine whether a BIPV system is expected to be a cost-effective addition to a building, other things being equal. For this purpose, the payback method is the least reliable, but in many cases, will also provide a clear indication of cost effectiveness and can be used as a screening tool. 
For designing and sizing BIPV systems, the net benefits method or the LCC method is recommended. As long as net benefits increase or LCC declines as more expensive designs are chosen or as system size is increased, it pays to go to the more costly design or larger system. The SIR and AIRR methods can also be used to design and size BIPV systems, but these methods must be applied to incremental amounts rather than to totals to be reliable (Ruegg and Marshall 1990).

For ranking non-mutually exclusive investment alternatives, SIR and AIRR are the preferred measures. In most cases, choosing projects in descending order of their SIR or AIRR until the budget is spent will result in maximum returns to the investor. The choice among technologies and the designing and sizing of the candidate systems can be combined in an overall optimization approach.

Criteria for cost effectiveness can be subjective depending on the investment decision maker. Generally, a project is cost effective if it has an SIR greater than one, an AIRR greater than the discount rate, an LCC lower than the next best alternative energy system, and a simple payback period shorter than the life of the BIPV system (see Table 1).

\section{Table 1: Minimum Evaluation Criteria}

\begin{tabular}{|l|l|}
\hline Evaluation Criteria & Economic Measure \\
\hline Payback Period & Payback Period $<$ Life of Building \\
\hline Savings-to-Investment Ratio & SIR $>1$ \\
\hline Adjusted Internal Rate of Return & AIRR $>$ Discount Rate \\
\hline Net Present Value & Net Present Value $>0$ \\
\hline Life Cycle Cost & Lower than LCC for Alternative \\
\hline
\end{tabular}

\section{Building Ownership Issues}

Given the inherent high initial cost and reduced operating costs associated with BIPV systems, investments are sensitive to and dependent on building ownership issues. The three primary types of building owners (owner-occupant, owner-investor, and owner-developer) differ in investment criteria and time horizons.

\section{Owner-Occupant}

An owner-occupant expects to own a building for a long time. This positions him or her to control the decisions related to the choice of the energy system. Minimizing the operating costs is in the owner-occupant's best interest. A higher initial capital investment may be acceptable if it will reduce operating costs. The owner-occupant may make investment decisions during the early stages of building design, construction, purchase, and renovation, and directly experience financial savings, system reliability, and building comfort. Consequently, the owner-occupant may be motivated to consider BIPV systems in new construction. But more often, the occupant will inhabit an established building and will not make the initial building design decisions. In these instances, it is advantageous for the building owner to consider retrofitting a PV system to that building.

\section{Owner-Investor}

An owner-investor will purchase and develop property to rent or lease to a third party. To maximize returns on investments, the owner-investor will be interested in minimizing O\&M costs unless the tenant is responsible for the user-energy costs. The owner-investor may consider solar 
technologies, such as PV systems, particularly if federal, state, or local government tax incentives provide the basis for an enhanced return on investment.

\section{Owner-Developer}

In this case, ownership is assumed to be temporary, from purchase through development and sale. Investment decisions will include energy-conscious design only if the owner-developer perceives that it will help sell the property to potential buyers who place value on energy features. Minimizing development capital costs is important to the owner-developer. Operating costs are not a primary consideration. Given the occasions of high initial capital costs and long-term returns associated with energy investments, there is little incentive to consider energy-conscious designs. The owner-developer may be able to capture tax incentives for implementing solar energy systems, but these benefits may not provide sufficient financial incentive to motivate the investment. In an even more negative scenario, the owner-developer may perceive that this technology and its associated costs will adversely affect the sale of the property and may actively avoid the investment.

\section{Evaluation}

Speculative building developers often base design and investment decisions on initial costs only. Future operating costs, including energy costs, may be considered in the financial decisionmaking process if the building is owner-occupied or if a potentially lower energy bill can be used as a marketing attraction.

Given that BIPV systems are capital-intensive investments with low operating costs, in most instances the long-term owner-occupant is best positioned to reap benefits from a system and, therefore, is the most likely investor. 


\section{Benefits of Building-Integrated Photovoltaic Systems}

The value of BIPV systems can directly affect the decision making process. The benefits can be identified and evaluated based on direct economic impact, indirect economic impact, and qualitative value. These three distinctive categories are defined below and followed by a series of arguments that benefit the application of BIPV. Numerous international examples are presented.

\section{Direct Economic Impact}

An integrated building energy system is generally procured through a construction budget. Electricity generated by the BIPV system creates savings that reduce operating budgets. A BIPV system can save the building owner money by reducing construction material costs and electricity costs, enhancing power quality and power reliability, and providing tax credits. The combined savings may accrue in a variety of budgets that will affect the investor's entire fiscal portfolio performance.

\section{Indirect Economic Impact}

Each building owner has a value related to strategic goals, business interests, or organizational mission. With a multifunctional BIPV system, additional costs and benefits may accrue and may not be obvious because of accounting methods and the directly and indirectly affected budgets. An organization may, for example, be able to assign a credit or value for BIPV for environmental emission reductions if they can be quantified, valued, and perhaps even traded. However, if an economic effect cannot be captured or understood by a decision maker, it is generally not included in the investment analysis.

\section{Qualitative Value}

Some benefits of BIPV systems are subjective. For the building owner, a considerable value of a BIPV system may be associated with a positive image, public perception, or impact on the built environment when the technology is installed.

Table 2 summarizes these values according to electrical, environmental, architectural, and socioeconomic aspects. In these guidelines, these benefits are considered subjective considerations. No dollar value will be assigned to them, but they do influence the value of the BIPV system to the consumer. 
Table 2: Summary of Nonenergy Benefits that Can Add Value to BIPV Systems

\begin{tabular}{|l|l|}
\hline Category & Potential Values \\
\hline Electrical & $\begin{array}{l}\text { KWh generated; kW capacity value; peak generation and load-matching } \\
\text { value; reduction in demand for utility electricity; power in times of emergency; } \\
\text { grid support for rural lines; reduced transmission and distribution losses; } \\
\text { improved grid reliability and resilience; voltage control; smoothing loan } \\
\text { fluctuation; filtering harmonics; and reactive power compensation }\end{array}$ \\
\hline Environmental & $\begin{array}{l}\text { Significant net energy generator over lifetime; reduced air emissions of } \\
\text { particulates, heavy metals, } \mathrm{CO}_{2}, \mathrm{NO}_{\mathrm{x}} \text {, and SO } \mathrm{S}_{\mathrm{x}} \text { resulting in lower greenhouse } \\
\text { gases, reduced acid rain, and lower smog levels; reduced power station land } \\
\text { and water use; reduced impact of urban development; reduced risks of } \\
\text { nuclear accidents }\end{array}$ \\
\hline $\begin{array}{l}\text { Architectural } \\
\text { Substitute building component; multifunction potential for insulation, } \\
\text { whading, thermal collection, and dissipation; aesthetic appeal through color, } \\
\text { transparency, nonreflective surfaces; reduced embodied energy of the } \\
\text { building; reflection of electromagnetic waves; reduced building maintenance } \\
\text { and roof replacements }\end{array}$ \\
\hline $\begin{array}{l}\text { New industries, products, and markets; local employment for installation and } \\
\text { servicing; local choice, resource use, and control; potential for solar } \\
\text { breeders; short construction lead times; modularity improves demand } \\
\text { matching; resource diversification; reduced fuel imports; reduced price } \\
\text { volatility; deferment of large capital outlays for central generation plant or } \\
\text { transmission and distribution line upgrades; urban renewal; rural } \\
\text { development; lower externalities (environmental impact, social dislocation, } \\
\text { infrastructure requirements) than fossil fuels and nuclear; reduced fuel } \\
\text { transport costs and pollution from fossil fuel use in rural areas; reduced risk } \\
\text { of nuclear accidents; symbol for sustainable development and associated } \\
\text { education; potential for international cooperation, collaboration, and long- } \\
\text { term aid to developing countries }\end{array}$ \\
\hline
\end{tabular}

Source: “Added Value of PV Power Systems," Report IEA PVPS T1-09: 2001.

\section{Building Functions}

A BIPV system is designed to serve more than one function. As a construction material, such as a BIPV glass facade, it is an integral component of the building envelope and generates electricity. Hence, it is defined as a multifunctional building material. Recognizing the financial value of displaced building materials and reducing installation costs could also improve the economics of BIPV systems. To be effective, BIPV products should match the dimensions, structural properties, qualities, and life expectancies of the materials they displace. Standardized construction glass, cladding, and roofing materials can then be easily integrated directly into the built environment.

\section{Example: Identifying Multiple Benefits}

A 13.5-kWp PV-integrated roof was installed at the visitor complex at the Centre for Alternative Technology in Wales. In addition to forming a waterproof layer, thereby saving on the cost of a separate waterproof layer for the roof, the system will save $10,000 \mathrm{~kg} / \mathrm{yr}$ in $\mathrm{CO}_{2}$ emissions. The system will also offset $80 \%$ of the $7.85 \mathrm{MWh} / \mathrm{yr}$ of diesel-generated electricity and will give 3 $\mathrm{MWh} / \mathrm{yr}$ back to the grid (Cadet Renewable Energy). 


\section{Promotional and Educational Benefits}

A BIPV system may have promotional and educational benefits. Technology demonstration provides education and outreach that correspond with some agencies' missions. If education is the primary purpose of the system, it is the deciding factor in using the technology. The economics of the system performance become ancillary. Cost justification, therefore, is not necessarily a requirement when a technology is used for demonstration.

\section{Example: Corporate Public Relations}

A BIPV installation at an environmentally conscious company could be used as part of a promotional campaign. The value of the installation is identified as a benefit to the company's public relations.

\section{Example: The Leasing Value of Enhanced Office Space}

In 1994, a BIPV facade was used to renovate the Ökotec office building in Berlin. The environmentally friendly aspect of this building technology was used as a marketing tool for leasing office space. In fact, the Ökotec building is the first new office building in the city to be fully occupied as a result of the attention given to the BIPV facade. The 8,100$\mathrm{m}^{2}$ building is almost completely powered by the energy generated by the facade, and excess energy is sold back to the utility grid. According to a May 1996 International Energy Agency (IEA) report, "Despite surplus office area in Berlin, the Ökotec building was almost completely rented immediately, following several press publications referring to the PV facade." This benefit could be treated as lost rent avoided in dollar value LCC analysis, provided the impact of the BIPV system on the probability of renting the space could be quantified (Okotec Office Building).

\section{Example: Business-Line Promotion}

A small family-owned business in Schluchse, Germany, expanded its facilities at Dilger Metallbau $\mathrm{GmbH}$ and created a building that would best represent its business. By designing the new building to present its strengths in architectural glazing systems and integrating custom-made BIPV modules, the owners have opened up many new possibilities in the marketplace. The building has surpassed performance expectations by gaining an early return on the investment and provides additional revenue sources from an expanded marketplace (Dilger Metallbau $\mathrm{GmbH}$ ).

\section{Thermal Benefits}

The energy generated by a BIPV system can be evaluated by assessing the cost of surplus electricity generated plus the system's energy contribution to the building's thermal performance. As such, the BIPV system can be designed according to the building's heating, cooling, and daylighting loads. For example, the use of semitransparent PV modules in atria is an excellent 
application of PV because it provides shading, reduces the cooling load, admits daylight, and generates electricity.

Another way BIPV systems may contribute to a building's thermal performance is through the thermal effect of the shading function on air conditioning loads, which a BIPV awning system provides during the summer.

In contrast to shading, the heat cogeneration of a $\mathrm{PV} / \mathrm{T}$ system provides another contribution to a building's thermal performance. For example, heat is produced when ambient air is vented behind the BIPV glass panels to cool the solar cells. (PV cells perform more efficiently at lower temperatures.) The captured warm air may then be used to preheat water or air for building services. However, technology review studies show that no acceptable technology is currently available for these medium-temperature applications.

\section{Example: BIPV Serving Multiple Functions}

Multifunctional covered parking systems One strategy for reducing the cost of PV systems is to use PV in applications with additional value beyond electric power production. In the example of covered parking, structural and land requirements for the PV system are eliminated. For new construction, the PV modules can provide shade and weather protection, resulting in an additional cost credit. In a few applications, the value of the shade may be much higher than the value of the electricity, so the value of the PV system/parking system combination may be as much as 5 USD/watt (W).

Assumptions:

- $18 \%$ of the full capital cost is needed each year for principal, interest, taxes, and insurance

- O\&M cost of 0.01 USD/kilowatt-hour (kWh)

- Electricity generation of 1,600 kWh/yr per installed kilowatt (kW)

- Electricity value of $0.10 \mathrm{USD} / \mathrm{kWh}$

- One kW covers 1.25 parking stalls

- Shaded parking costs 2.00 USD/day per parking space

- Utilization factor of 0.9. A parking stall is assumed to be used $90 \%$ of the time

Covered parking can be very popular at an airport where the climate is extremely sunny and hot, and $2.00 \mathrm{USD} /$ day is relatively inexpensive for parking.

Based on the assumptions, the annual value of a $10-\mathrm{kW}$ PV covered parking system is:
Electricity value
1,600 USD
Shade/weather protection value
8,212 USD
Total annual value
9,812 USD

For comparison, the annual cost of a $10-\mathrm{kW}$ installation at 5,000 USD/kW:

Capital costs

9,000 USD

O\&M costs

160 USD

Total annual cost

9,160 USD

A typical cost for a covered parking stall is about 600 USD, or 0.75 USD/W, assuming 800 W AC per stall. 


\section{Example: PowerLight's PowerGuard System}

Patented by PowerLight Corporation, the PowerGuard System tiles incorporate PV cells backed with insulating polystyrene foam, turning the sun's free energy into usable power while increasing building thermal insulation and extending roof life. PowerGuard works over new roofs and as a retrofit over established roofs. The system protects the roof membrane from harsh UV rays and thermal degradation for 30 years. It also reduces air conditioning and heating costs with R-19 insulation and roof shading.

\section{Example: Sunshading in Korea}

Approximately $35 \%$ of Korea's total energy consumption is used to heat and cool buildings. One way to help reduce this number is to design buildings that use sunshading to help reduce the heat gain in the summer and heat loss in the winter.

The Institute of Construction Technology at the Samsung Corporation in the Gihung area installed PV sunshade models over the windows, as well as roof-mounted PV modules, making it the first BIPV system in Korea.

During 1997, data were collected on the temperature differences in the air surrounding the PV module. The results showed a significant temperature difference between the shaded and unshaded modules (Yoo, Lee, and Lee 1998).

\section{Example: Cooling Panels and Preheating Air with BIPV}

In Europe, the first documented building with a hybrid BIPV/SolarThermal system is the Aerni Fenster Factory in Switzerland. In 1993, the hybrid BIPV system produced $70 \%$ of the combined electrical and thermal requirements of the factory.

The BIPV system is composed of an 8-kW BIPV facade and a 53-kW BIPV skylight system. By cooling the backsides of the panels with ambient air, the equivalent of 115 $\mathrm{kW}$ of thermal power is captured to heat the factory. This significantly increased the economic performance of the PV/solar thermal system.

\section{Electricity Benefits}

The value of electricity generated by a BIPV system is determined by the amount of electricity consumed plus the value of surplus electricity generated. Typically, facility electricity bills are paid monthly from annual operations budgets. The O\&M budget will decrease by using the solar energy source. The value of BIPV electricity generation to the building owner is the difference of the estimated baseline energy bill and the actual cost of the solar energy source. If a backup system is installed, the costs of backup fuel, O\&M, and depreciation must also be considered 
when determining the value of BIPV electricity generation. As the number of running hours decreases, O\&M costs in particular can be dramatically reduced by installing a PV system.

\section{Metering}

Metering can account for the electricity generated by BIPV systems and allow the building owner to be paid retail electricity rates or utility-avoided cost rates for surplus energy generated by gridconnected BIPV systems. A commercial or institutional building is occupied during daytime hours and generally will consume all the BIPV electricity produced. However, for more than onethird of annual daylight hours, most commercial office buildings and institutional buildings are unoccupied, and surplus energy may be generated on weekends and holidays. If the energy generated by a grid-tied BIPV system exceeds the power required for security, communication, or refrigeration systems in an unoccupied building, the utility company may purchase the surplus electricity at an agreed upon rate. Net billing bills for electricity provided by the utility less the surplus sold back to the utility and credits the difference if the surplus exceeds the electricity purchased. To encourage private investment in renewable energy technologies, regulatory authorities may mandate net billing.

The economic value of BIPV metering can be easily identified and measured by the annual or monthly dollar reduction of the facility's energy bill. Net billing accounts for the electricity generated by the BIPV system by paying the producer for surplus energy either at retail electricity rates or utility-avoided cost rates. Retail rates versus avoided costs can significantly affect the economics of BIPV systems. These two accounting methods, dual metering and net metering, are discussed below.

\section{Dual Metering}

In this method, avoided cost accounts for the utility's marginal cost of fuel and is a relatively low electric rate compared to the retail rates. In practice, the value of PV electricity is determined relative to coal-fired $\mathrm{kWh}$ power. This requires two meters to be installed on the facility premises: one each to account for imported and exported electricity. This requires additional hardware and duplicate systems for accounting purposes only and does not complement the multifunctional simplicity of BIPV technology.

\section{Net Metering}

Where retail net billing is permitted, the accounting method for importing and exporting electricity uses standard electric meters that can run forward and backward. When the BIPV power system produces more electricity than the building consumes, the meter runs backward. The meter registers the net energy, consumed or produced, and the occupant is billed or credited accordingly at the end of the monthly billing period. This provides a more efficient accounting method and benefits the utility by reducing marginal energy costs and using less hardware than dual metering.

Net metering benefits the power generator by providing retail rates for surplus electricity. During the billing cycle, if the BIPV system produces less power than required, the retail rate is paid to the utility. If excess power is produced, the lower wholesale rate or the rate set by the regulatory authorities is paid to the building owner.

In summary, one form of net metering uses a standard meter that runs forward and backward; the other uses two meters (or a dual counter meter) with one running forward and one backward. Although the one-meter concept is the best by far, one meter running two ways is impossible in 
countries (such as the Netherlands) that use electronic meters. Even though the power flows from the PV system to the main, the counter will not run backward, essentially meaning that the rate of PV power sold back to the utility is reduced to zero.

\section{Example: Effects of Net Metering on Utility Bill with Solar}

Net metering encourages direct customer investment in small-scale renewable energy systems, simplifies interconnection by avoiding meter replacement, improves economics of small-scale renewables, and reduces metering and administrative costs for the utility (Starrs 1999).

Assumptions:

- 2-kWp solar PV system

- PV system generates $263 \mathrm{kWh} / \mathrm{month}$

- Residence uses $600 \mathrm{kWh} / \mathrm{month}$

- Retail price is $0.06 \mathrm{USD} / \mathrm{kWh}$

- "Avoided cost" price is $0.02 \mathrm{USD} / \mathrm{kWh}$

- PV-to-load ratio is 0.40

\section{Example: Net Metering}

State: New York

Eligible technologies: photovoltaics

Applicable sectors: residential, investor-owned utilities

Legislative code: 1997 Assembly Bill 8660, Senate Bill 5400

Incentive type: net metering

Date enacted: August 2, 1997

Expiration date: none

In the summer of 1997, New York enacted a net metering law for residential PV systems $10 \mathrm{~kW}$ or smaller. A similar law was vetoed in November 1996 over concerns about interconnection safety issues. New York's new net metering law also includes an income tax credit allowing residential customers to claim $25 \%$ of the cost of a qualifying PV system. The utilities are obliged to accept customers into the net metering program under a first come, first serve arrangement until the capacity signed up for net metering equals $0.1 \%$ of the utility's 1996 peak demand. Individual utilities, however, can choose to allow a greater capacity to enroll in net metering. At the end of each month, net excess generation is credited toward the following month's bill. If the customer has generated any net excess electricity, that customer is paid the utility's avoided cost for that generation.

\section{Demand Savings}

Demand savings offers an opportunity to maximize the economic performance of BIPV systems. Utilities apply a demand charge relative to the peak energy load for a building. A periodic average reading of the building's electrical consumption (e.g., every 15 minutes) determines the peak electrical demand. BIPV systems are subject to climate and weather conditions-a passing cloud may diminish the system's performance in an instant and the demand savings would not be realized. Therefore, having no backup storage system, such as a battery bank, may yield only uncertain savings. A backup system will also incur costs for design, hardware, maintenance, and battery replacement. At that point, the demand savings benefit of the backup system must be weighed against the additional costs. 
Under the PV: BONUS Program in the United States, the University of Delaware's Center for Energy and Environmental Policy and the Applied Energy Group have developed a dispatchable peak-shaving system with battery storage to reduce the time-of-day charges. This system could also be designed and sized to reduce demand charges. It is currently being tested and monitored in five U.S. locations.

\section{Power Quality and Reliability}

The measure of value attributed to electric power quality and reliability depends on facility operations. Power quality problems, such as equipment incompatibility within the electrical power supply, reflect system disturbances that can cause equipment malfunctions and even power outages. A power quality problem most likely occurs if the power supplied to a piece of equipment is subject to high levels of fluctuations, harmonics, sags, swells, dips, spikes, flickers, and outages, and the equipment cannot handle these faults without shutting down or being damaged. BIPV systems can be designed to augment power quality by serving a dedicated load. Unfortunately, the value of power quality may be difficult to quantify. It can be increased to ride over a brownout if the PV system provides voltage support at the load (Coles et al. 1995).

To achieve power reliability, uninterruptible power supply (UPS) systems are designed and incorporated into building energy systems to protect specific equipment or critical loads from power interruptions. The additional equipment required includes batteries, a storage area, controllers, and associated electronics. A BIPV system could similarly be designed and sized to serve an isolated load in the building that would automatically separate from the utility grid if a line disturbance or power outage is detected (Coles et al. 1995). The benefit of such a system can be expressed as the avoided cost of an emergency backup power source.

Studies have been conducted on the additional value of PV as an emergency power supply for reliability (Byrne et al. 1997). A device has been designed that can shave peak electricity demand and switch to a UPS system when a power outage occurs. Power quality and reliability are the benefits of such a system. Wilk et al. (2001) reported on these items and presented electric schemes and an example of the Suglio building in Switzerland. As with demand savings and UPS systems, additional hardware must be purchased for a reliable power benefit. The specific battery storage capacity would have to be engineered and sized to meet the building's needs and energy loads.

\section{Photovoltaics Benefits to Grid Support}

The Kerman PV plant is part of the Pacific Gas \& Electric (PG\&E) utility system in California. Kerman is the first and largest plant designed and built to measure the benefits of grid-supported $\mathrm{PV}$. The plant, designed at $500 \mathrm{~kW}$ AC and rated by PVUSA at $498 \mathrm{~kW} \mathrm{AC}$, was completed in 1993. Nontraditional benefits consist of externalities from reduced fossil fuel use, local reliability enhancements, real and reactive energy loss savings, deferral of transformer replacement and load-tap-changer maintenance, transmission capacity deferral, and power plant dispatch savings. Table 3 summarizes the estimated value of these benefits and shows nontraditional benefits ranging from a low of $138 \mathrm{USD} / \mathrm{kW} / \mathrm{yr}$ to a high of $214 \mathrm{USD} / \mathrm{kW} / \mathrm{yr}$. IEA PVPS Task 5 is working on this issue in more detail. 
Table 3: Kerman Photovoltaic Plant Nontraditional Benefits (USD 1995) (Wenger, Hoff, and Farmer 1994)

\begin{tabular}{|l|l|l|c|c|}
\hline Benefit & $\begin{array}{l}\text { Definition and } \\
\text { Economics Driver }\end{array}$ & $\begin{array}{l}\text { Technical Validation } \\
\text { Results }\end{array}$ & $\begin{array}{l}\text { Nominal } \\
\text { Estimate } \\
\text { (USD/ } \\
\text { kW/yr) }\end{array}$ & $\begin{array}{l}\text { High } \\
\text { Estimate } \\
\text { (USD/ } \\
\text { kW/yr) }\end{array}$ \\
\hline Externalities & $\begin{array}{l}\text { Generation fuel mix and } \\
\text { externality valuation }\end{array}$ & $\begin{array}{l}\text { Offset 155 tons of } \mathrm{CO}_{2} \text { and } \\
\text { 0.5 tons of } \mathrm{NO}_{x} \text { each year }\end{array}$ & 31 & 34 \\
\hline Reliability & $\begin{array}{l}\text { Postpone planned reliability } \\
\text { improvements }\end{array}$ & $\begin{array}{l}\text { Voltage support of 3V per } \\
120 \mathrm{~V} \text { base }\end{array}$ & 4 & 4 \\
\hline Loss Savings & Reduce kWh and kVAR losses & $\begin{array}{l}\text { Save 58,500 kWh and 350 } \\
\text { kVAR each year }\end{array}$ & 14 & 15 \\
\hline Substation & $\begin{array}{l}\text { Reduced transformer upgrade } \\
\text { expenditures }\end{array}$ & $\begin{array}{l}\text { Transformer cooling } \\
\text { increases capacity by 410 } \\
\text { kW at peak; extend load- } \\
\text { tap-changer maintenance } \\
\text { by more than 10 years }\end{array}$ & 16 & \\
\hline Transmission & $\begin{array}{l}\text { Marginal cost of transmission } \\
\text { capacity }\end{array}$ & $\begin{array}{l}\text { Increase of 450 kW on } \\
\text { peak }\end{array}$ & 45 \\
\hline Minimum \\
Load
\end{tabular}

\section{Utility Incentives}

A variety of utility incentive, energy conservation, and demand-side management programs were successful during the 1980s. These arrangements provided a win-win scenario in which the consumer reduced energy consumption and the utility controlled its load growth. In the United States, the Utility PhotoVoltaic Group (UPVG) is a nonprofit organization funded by the U.S. (DOE). UPVG comprises more than 85 member utilities and is involved in a wide range of activities that support the development of PV as an energy supply. The UPVG provides utility and customer incentives, such as cost sharing, to accelerate the commercialization of PV technology.

As the utilities are faced with the uncertainties and competition associated with deregulation, there is a strong economic incentive to maintain and build on its customer base. Consequently, some utilities offer special customer services, such as "green power" generated by PV. Under these programs, the consumer agrees to pay more for electricity generated from environmentally friendly sources (see www.greenprices.com).

Some utility companies have rate structures with differing time-of-day rates. Typically, a BIPV system will produce electricity during the daytime peak rate hours and provide a high value of avoided electricity costs. If a building is subject to time-of-day usage rates, the economic benefit of PV-generated power can be included as a direct fiscal impact.

\section{Utility Incentive Programs}

Utility incentive programs may provide innovative financing and contractual mechanisms for energy conservation measures and the implementation of renewable energy technologies. Incentives may include system buy-down or cost sharing, leasing, financing, hosting systems, and net metering. 


\section{Example: Utility Rate-Based Incentives}

An important market development for PV is growing in Germany. Rate-based incentives allow the public to install PV systems and recover investments over time through a perkilowatt-hour payment for clean energy generation. The payback is funded through a low surcharge on electric utility bills.

The first known initiative dates from 1994 when the city of Aachen implemented a ratebased incentive program. PV investors receive $2 \mathrm{DM} / \mathrm{kWh}$ (1.34 USD/kWh) so they can fully recover their cost of purchasing and installing the PV system. The $2 \mathrm{DM} / \mathrm{kWh}$, periodically subject to reviews, is paid for 20 years, the average life of a PV system. The surcharge on electricity bills is less than $1 \% / \mathrm{kWh}$, which essentially means utility ratepayers are asked to contribute less than half a dollar per month to support clean energy generation and improve the environment (Solarenergie-Forderverein 1994).

\section{Example: Switzerland's Solarstrom Stock Exchange}

The original model of the "Solarstrom Stock Exchange" created for the promotion of solar electricity has evolved into a very successful project. At the beginning of 2000 , 1,570 kW nominal PV power was installed and 42 PV power plants are under contract, producing a total solar electricity value of $1,200,000 \mathrm{kWh} / \mathrm{yr}$.

A total of $5,700 \mathrm{EWZ}$ customers ordered more than $850,000 \mathrm{kWh}$ of solar power at a current price of $0.65 \mathrm{USD} / \mathrm{kWh}$. Negotiations with suppliers indicate that prices for solar electricity are available below the $0.50 \mathrm{USD} / \mathrm{kWh}$. Cost reduction of $20 \%$ for installed PV plants could be achieved in the EWZ "Solarstrom Stock Exchange" mode (Ruoss 2000).

\section{Security}

Concerns regarding energy security can range from petty vandalism to international terrorism. The use of BIPV technology as backup power or uninterruptible power supply (UPS) is a possible solution to such crimes. Standard UPS systems operate within a brief 3-second to 3-minute time frame. PV systems with accompanying battery storage can provide long-term backup power for days. The value of the PV system providing security, which would not be obtainable by any other means, could offset the current market cost of the system.

\section{Environmental Benefits}

When generating electricity, BIPV systems produce no harmful environmental emissions. A stakeholder can account for avoided environmental costs associated with not using power generated by fossil fuels. This value can be included in an LCC analysis. However, this value should not be considered when assessing decisions in which environmental effects play no role 
(e.g., energy savings performance contracting would not include qualitative environmental benefits that do not directly affect cash flow in the economic analysis).

Noise is also an environmental concern that has been addressed by PV and transportation engineers. As part of the infrastructure, noise barriers offer an additional and clever opportunity to integrate PV. The first PV noise barrier was constructed in 1989 near Chur, Switzerland. Six more prototypes have been built in Germany and Switzerland as a result of an international idea competition.

\section{Example: National Environmental Strategies}

Australia is incorporating PV programs into its greenhouse gas reduction strategies and clean air programs. An Australian commercial high-rise PV-integrated building illustrated this goal by reporting reductions of 1,640 tons of $\mathrm{CO}_{2}$ per annum (Wren and Barram 2000).

\section{Example: Sound Barriers}

Figure 1 shows the average costs of traditional sound barrier materials in Germany, including labor and engineering. PV materials can substitute or displace a considerable part of the costs. The transparent materials may be the most interesting materials to substitute.

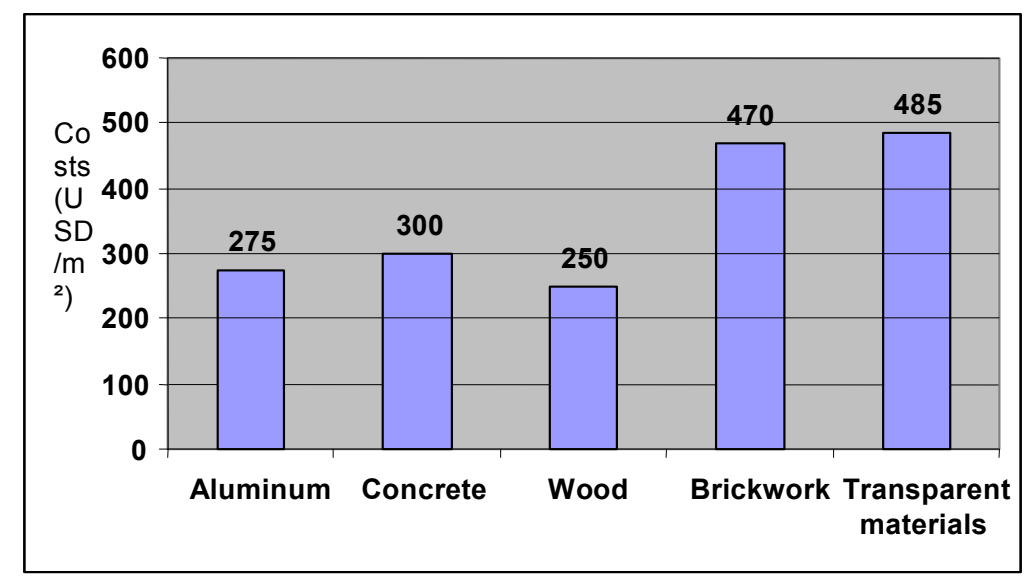

Figure 1: Average costs of traditional sound barrier materials (Germany 1996). 


\section{Example: Environmental Benefits}

The world's largest and most technically advanced rooftop PV plant is installed on top of the New Munich Trade Fair Center. This grid-connected system, with a peak output of $1 \mathrm{MW}$, has supplied more than 1 million $\mathrm{kWh}$ of electrical energy in the past 12 months. This is equivalent to the annual power consumption of about 340 German households and has meant a reduction in carbon dioxide emissions of 1,000 tons per year (Fact Sheet: New Munich Fair Trade Center).

\section{Example: Avoided Environmental Emissions Costs}

According to the U.S. Department of the Interior (DOI), National Park Service (NPS), Denver Service Center (DSC) Guideline 82-1, in all LCC assessments, environmental emission costs will be part of the analysis. This is applicable to new construction, renovation, and power system replacement. NPS, DSC Guideline 82-1, Amendment No. 3 quantifies the environmental emissions cost of electrical power generation and the resulting emission releases.

The NPS has determined the environmental cost associated with $\mathrm{CO}_{2}$ emissions to be $0.004 \mathrm{USD} / \mathrm{lb}(0.0088 \mathrm{USD} / \mathrm{kg}), \mathrm{SO}_{2}$ emissions to be $0.75 \mathrm{USD} / \mathrm{lb}(1.65 \mathrm{USD} / \mathrm{kg})$, and $\mathrm{NO}_{\mathrm{x}}$ emissions to be $3.40 \mathrm{USD} / \mathrm{lb}$. (7.48 USD/kg).

\section{National Incentive Programs}

BIPV installations are becoming commonplace around the world. Governments can make a great impact on the commercialization and widespread use of this technology through the implementation of national incentive programs for early adopters of the technology. Currently one of the most comprehensive national incentive programs is in the Netherlands, where the government is working with the PV industry, the building sector, and utilities to make PV commercially viable within the next 7 to 10 years. PV system costs have fallen from 17 Euro in 1991 to 5 Euro in 2000 as a result of the "PV Learning Program," a 1996-2000 incentive program (Schoen 2000).

\section{Example: National Incentive Programs in Germany}

On February 25, 2000, the German Parliament adopted the Renewable Energy Law (REL) for the priority access of electricity from renewable energy sources. The REL combines the elements of the 1990 Electricity Feed Law and a flexible quota on the electricity supplier level. Its overall objective is to contribute toward doubling the share of renewable energy in the electricity market from $5 \%$ to $10 \%$ by 2010 . This is in line with targets set in the European Commission's 1997 Renewable Energy White Paper.

By setting specific tariffs for each renewable energy technology based on its real cost, the law clearly recognizes the contribution of renewable energy to reducing greenhouse gas emissions and saving fossil fuel reserves. Its aim is to initiate a self-sustaining market for renewables by compensating for the distortions in the conventional electricity 
market. It also creates critical mass by a significant market introduction program that does not lead to any additional burden for the taxpayer. Under this framework, renewables are to be made competitive with conventional energies in the mid- and long-term. The REL includes digressive and differentiating elements, and a biannual revision process that allows for a regular adaptation according to technological and market development. A time limit of 20 years is set for each power plant.

\section{The Challenge of Falling Electricity Prices}

As liberalization and increasing competition have developed rapidly in the German electricity market since 1998, a new concern has arisen for renewable energies. The drop in the tariffs paid by consumers has led to a similar decrease in the renewable energy feed-in tariffs (REFITs), which are linked to average electricity prices. The new situation is worrisome to financial institutions, wind turbine manufacturers, owners, and potential developers. It started to endanger the viability of current and proposed projects, which are moving increasingly inland because of site restrictions in the more windy coastal areas. The government has therefore followed a new approach, moving away from a system in which the REFITs are linked to the average electricity tariff and toward a more clearly fixed price based on actual generation cost.

\section{Encouraging Solar, Biomass, and Geothermal Electricity}

The new law applies to power generated wholly from any wind, solar, or geothermal source; from hydro, landfill, sewage, or mine gas plants $5 \mathrm{MW}$ or smaller; and from biomass sources of $20 \mathrm{MW}$ or lower. Geothermal is added, and the rated capacity for a biomass plant has been raised from $5 \mathrm{MW}$ to $20 \mathrm{MW}$.

Solar PV systems will now receive DM 0.99/kWh $(0.50 €)$, with a degression of $5 \%$ for new installations starting in 2002, which reflects the expected cost reduction potential of a technology that is still the least economic of all renewables. A new scheme has to be put in place as soon as an installed PV capacity of $350 \mathrm{MW}$ is reached.

\section{Grid Connection Costs}

For the first time, the costs for grid connection, as well as for grid enforcement and extension, are set in the law on the basis of reliable and fair terms. The costs for grid connection are to be paid by the developer. Transparency will increase because developers have the right to ask an independent third party to take care of the technical connection of the wind farm. However, the costs for grid extension or reinforcement that might ultimately be required in certain cases must be borne by the grid operator, who is allowed to add these costs as a surcharge on the grid fee.

\section{Utilities Eligible for REFITs}

Another important change compared to previous legislation is that electricity companies will be eligible for the new REFIT rates. We hope that this would end their opposition against the renewable energy legislation, and we expect an additional market stimulus by widening the scope of the REL. 


\section{Example: National Incentive Programs in the United States}

The U.S. National Database of State Incentives for Renewable Energy (DSIRE) - through the Interstate Renewable Energy Council (IREC)-surveys each of the 50 states for available information on financial and regulatory incentives. These incentives are designed to promote the application of renewable energy technologies. This information is being developed into a database that will detail the state-by-state incentives. Much of the database is accessible via the Internet; states will find it easy to retrieve information for analyzing and replicating successful incentives.

The North Carolina Solar Center is the principal subcontractor to IREC for collecting and preparing the information. Some financial and regulatory incentives are identified by state, end-use sector, technology, and incentive type. The mechanics of financing and regulatory tools are available in the form of files and documents pertaining to statutes, legislation, fact sheets, brochures, and reports.

In the rapidly evolving power industry, DSIRE (http://www.dsireusa.org/) can be the most effective method of obtaining current information. The following electronic resources are available: a table of state financial incentives, a table of state programs and regulatory policies, a searchable online database, a technical paper on DSIRE, and links to downloads.

\section{Example: Environmental Benefits of Solar Energy}

As solar energy displaces other energy sources with higher emission levels, it reduces emissions of pollutants. The EPA Solar Power Calculator estimates $\mathrm{SO}_{2}$ and $\mathrm{NO}_{\mathrm{X}}$ emission reduction benefits using information from the Emissions and Generation Resource Integrated Database, which provides data on emissions associated with electric power generated by U.S. utilities. $\mathrm{CO}_{2}$ emission reductions are based on a model that simulates marginal reductions in electricity use. In the calculator, emission factors (expressed in pounds of pollutant per $\mathrm{kWh}$ of electricity) are multiplied by reduced electricity use (http://www.mrsolar.com/calcstate/calc.htm). 


\section{Example: Buydowns in California}

The 1996 California restructuring law (AB 1890) provided 540 million USD for a Renewable Resources Trust Fund supporting renewable generating technologies. This fund will be used to provide rebates, or "buydowns," to customers who purchase smallscale renewable energy systems. The amount of the buydown will decline over the life of the program, starting with a block of funds at 3 USD/W and ending with a final block of funds at $1 \mathrm{USD} / \mathrm{W}$. If only half the funds go toward grid-connected PV systems, California is likely to have $15 \mathrm{MW}$ of new grid-connected PV generation in place within 5 years. This would roughly double the total grid-connected PV generation in the United States.

The California Energy Commission is offering cash rebates on eligible renewable energy electric-generating systems through the Emerging Renewables Buydown Program. In Spring 2001, the Commission approved a rebate increase from 3,000 USD $/ \mathrm{kW}$ to $4,500 \mathrm{USD} / \mathrm{kW}$, or $50 \%$ off the system purchase prices (whichever is less). All types of electricity customers-residential, commercial, agricultural, and industrial-are eligible. This rebate makes it more affordable for customers to generate electricity using renewable energy. System requirements are:

- The system's electricity production should not exceed $200 \%$ of the site's historical or current electricity needs.

- The retailer must provide a minimum 5-year warranty.

- Individuals may install their own systems or have them installed by a licensed contractor. Labor costs of the contractor-installed system can be counted toward total eligible system costs. A "do-it-yourselfer" cannot include his or her labor cost as part of total eligible system costs.

- System components must meet national standards.

- Customers may purchase their electricity from any electric service provider, but the proposed site must be within the electric utility service areas of PG\&E, San Diego Gas \& Electric, Southern California Edison, or Bear Valley Electric Company.

- Customers must be and remain connected to the utility grid.

\section{Loan Incentive Programs}

The government can absorb risks by allowing the private sector loan recipient to benefit from the government's economy of scale in raising funds and insuring risks. This reduces the capital cost by directly subsidizing interest rates, eliminating the premium charged by the lender for default risk, allowing favorable repayment terms, or by operating insurance programs at a loss.

An investor or financier may perceive a BIPV system to have a greater risk than traditional gridsupplied electricity. The government can enact legislation that provides the means and opportunity to (1) specify regulations that can minimize the risk associated with a new technology to satisfy the risk assessment requirements of lending institutions, and (2) provide financial incentives for building owners to make private investments. 


\section{Example: Interest Rate Reduction}

A one-eighth point reduction on a residential home loan is available through the U.S. Environmental Protection Agency's Energy Star ${ }^{\circledR}$ mortgage program.

A 20,000-USD BIPV roof system on a 200,000-USD home would result in a reduction of the interest rate on the full 220,000 USD mortgage over the life of a 30-year loan. This results in a savings of approximately $18 \mathrm{USD} /$ month, or 6,400 USD over the life of the loan.

Hence, the BIPV installation would reduce not only the homeowner's monthly utility bill, but also the mortgage bill.

\section{Example: The Economic Impact of High Interest Rates}

In Edmonton, Canada, a capital cost of $0.37 \mathrm{CAN} / \mathrm{kWh}$ is charged if spread interest-free over a 25-year period, but if a $6 \%$ interest rate is included, the cost jumps to 0.93 $\mathrm{CAN} / \mathrm{kWh}$. PV technology produces high-value electricity, and this compares with the residential rate of $0.0715 \mathrm{CAN} / \mathrm{kWh}$ in Edmonton.

This high interest cost is in addition to the PV systems cost and installation of 28,000 CAN, or 12 CAN/W, in 1995. By 2005 , this number is expected to be reduced by $60 \%$.

\section{Example: Increased Debt-to-Income Ratio "Stretch"}

This ratio compares a borrower's expenses and income to determine the borrower's ability to meet monthly financial obligations. The U.S. Veteran's Administration allows the loan value to be increased up to $\$ 6,000$ if the increase in the mortgage payment is matched by the reduction in the utility bill. This allows the veteran to borrow more money to install solar equipment.

\section{Example: Loan Guarantee}

The U.S. Small Business Administration (SBA) provides a loan guaranty program 7(a), which transfers the risk of borrower nonpayment, up to the amount of the guaranty, from the lender to the SBA. The business applying for an SBA loan is actually applying for a commercial loan with an SBA guarantee. The government will reimburse the lender for any loss, up to the percentage of SBA's guarantee. These types of loans guarantees encourage lenders to provide funds for solar electric systems, even though the lenders are unfamiliar with the technologies. 


\section{Example: Loan Incentive Programs}

Germany's "100,000 Roofs Program" (2000-2003) is an example of a loan incentive program. This soft loan is distributed through the federal development bank with a $0 \%$ interest rate. The local banks, which offer the loan to end users, receive a low margin for their transaction costs and risk approval. The local banks bear the credit risks, but the federal bank can overtake $50 \%$ of the total risk by reducing the bank's margin. The program is a 10 -year credit with a 2 -year grace period, equivalent to a $37.5 \%$ subsidy. This program can be used in conjunction with rate-based incentive programs.

\section{Tax Incentives}

Government tax policy determines whether there will be tax incentives. Tax incentives are designed by public policy makers to encourage private capital investments that might not ordinarily occur. Solar tax credit legislation is designed to stimulate the social and institutional acceptance and accelerate the economic development of the industry by encouraging private investments in PV systems.

Solar tax legislation can influence the development of technical expertise through industry and trade association labor certification, bonding requirements, product quality, warranty and guarantee coverage requirements, and system certification to meet building codes. This legislation can be technically specific and disseminate educational and state-of-the-art information about BIPV systems. Federal regulations can reduce the investment risk to the lender and act as a financial incentive for the consumer or manufacturer to invest in the technology.

Four categories of taxation incentive programs may apply to BIPV systems: tax credits, tax rate, tax basis, and taxable entity.

\section{Tax Credits}

Tax credits permit a percentage of expenditures to be deducted from the net taxes owed to the government. Taxation parameters are generally divided into federal, state, and local tax obligations.

\section{Tax Rate}

A reduction to the tax rate can provide a financial advantage in three ways:

(1) It can exempt certain activities, products, or entities from taxation, or tax them at a lower rate than their market substitutes.

(2) Entire entities (such as some publicly owned electric utilities) may be exempt from federal income tax, even though they compete with other providers of the same service. A lower tax rate may permit a particular type of firm to pay a lower percentage tax on certain activities (lower tax rates on capital gains).

\section{Tax Basis}

The tax basis can be reduced by decreasing the taxable income on which a given tax percentage is applied. This is accomplished by accelerating the timing of the tax deduction or by excluding portions of income subject to taxation. Firms may be allowed to deduct costs of PV investments from taxable income much faster than the investments actually depreciate. The reduction in 
current taxes is greater than the reduction in future taxes. The current tax savings (for example, accelerated depreciation on plant and equipment) can also be invested and can earn interest.

\section{Taxable Entity}

Altering the taxable entity will affect the definition of a taxpayer. This change may enable profits to be offset by losses and have a beneficial effect on tax calculations. Exceptions to rules on consolidating tax returns can give rise to subsidies, which allow profits to be shifted in a large, vertically integrated corporation (such as an oil company). For example, when the taxable entity is difficult to define and transactions among divisions are conducted at artificially set transfer prices, profits can be shifted among divisions and countries to minimize the tax burden.

\section{Examples: State Tax Incentives}

There is a wide variety of tax legislation among the 50 states. For example, North Carolina has instituted a $35 \%$ income tax credit allowance for commercial buildings with PV systems; South Carolina has no such legislation.

\section{Property Value}

In California, a BIPV system does not add to the assessed property value until the property is sold (Freedman et al. 1995).

\section{Sales Tax Recovery}

In Connecticut, the sales tax paid on a BIPV system can be recovered when filing an annual tax return (Freedman et al. 1995).

\section{Accelerated Depreciation}

In Texas, a commercial business that invests in the installation of a BIPV system may apply an accelerated depreciation of franchise tax over 5 years (Freedman et al. 1995).

\section{Reduction in Tax Basis}

In Hawaii, the net income tax credit for BIPV systems is $35 \%$ or 1,750 USD maximum for a single-family residence, $35 \%$ or 350 USD maximum for multiunit buildings, and $35 \%$ for commercial buildings with no maximum (Freedman et al. 1995).

\section{Example: U.S. Tax Incentives}

Currently, the U.S. government allows a $10 \%$ tax credit to offset the cost of PV systems in commercial buildings. The Federal Solar Energy Tax Credit is augmented by state tax policies, based on local initiatives.

\section{Energy Tax}

Apart from tax incentives, one can also induce energy taxes on nonrenewable sources. A growing number of EU countries (Sweden, Denmark, Germany, the Netherlands) have such taxes; an EU Energy Tax is under debate. 


\section{Costs of BIPV Systems}

Next to the benefits of BIPV, costs are important to performing the economic analysis. This section characterizes the relative costs of BIPV systems for the building owner. Limited objective published data are available on BIPV system costs. A preliminary survey indicates a wide variation in cost estimates provided by various manufacturer marketing representatives. Consequently, a variety of vendor bids should be gathered and reviewed before an investment decision is made.

The BIPV system cost (technology related) depends on the type and size of system, current PV technology, and whether a custom product or a standardized manufactured product is used. Two primary types of commercial BIPV products - facades and roof materials-are available for new construction and renovation projects. BIPV facade systems include laminated and patterned glass, spandrel glass panels, curtain wall glazing systems, cladding systems, and awning systems. These products can displace traditional construction materials. Roofing systems include BIPV shingles, tiles, metal roofing, exterior insulation roof systems, and atrium or laminate roof systems. These products can displace traditional construction materials or be sold as enhanced construction materials.

As such, the added cost for a BIPV system (rather than the full costs) should be used in economic assessments, including those that would be incurred regardless of the BIPV system. If, after a preliminary screening, the economics are favorable for a BIPV system investment, a formal bid from the system supplier can be used to evaluate the system cost and benefits in more detail before purchase. The total BIPV system cost can then be compared to conventional building component costs to determine the added cost of the BIPV system.

\section{Building-Integrated Photovoltaic System Costs}

BIPV systems are composed of PV modules and balance of system (BOS) components, which include inverters, an electricity storage system, and/or a grid-metered connection, fault protection, cabling, and wiring. These costs, as well as the costs of integration design and installation, should be evaluated in comparison to the traditional construction products and systems to determine the marginal cost of the BIPV system.

PV manufacturers are in the early stages of technology development and commercialization and do not have the capacity to take advantage of quantity purchases of materials and of large-volume production to offer lower-priced BIPV components and systems. Nevertheless, the cost of PV technology has declined because of technical advances. In addition, industry and government foresee further cost decreases as the demand for PV technology increases internationally and manufacturing economies of scale increase.

BIPV can be incorporated into new constructions at a relatively small additional cost. When compared to more conventional cladding materials such as glass or steel, installing photovoltaics adds only a marginal extra cost $(2 \%-5 \%)$ to the total construction costs of a commercial building. 


\section{Example: Cost Comparisons: Traditional PV versus BIPV}

In one PV application study for commercial building facades, two mounting cases were considered: a standoff technique recently used on the headquarters of IKEA in Almhult, Sweden, and direct mounting into a Kawneer 1600 Wall curtain wall using the PowerWall ${ }^{\mathrm{TM}}$ system.

This case illustrates the substantial cost advantages of truly integrated systems. The integrated system saves $\$ 1.62 / \mathrm{Wp}$ (USD), or $28 \%$, over a standoff system. Not only are the costs of the separate mounting structure and installation eliminated, the cost of a normal spandrel infill is also saved, resulting in a credit toward the cost of the PV system of $\$ 0.50 / \mathrm{Wp}$. This figure assumes that an inexpensive fritted glass infill would otherwise be used. Some spandrel materials are many times as expensive.

Table 4: Cost Comparison between Stands

\begin{tabular}{|l|c|c|}
\hline$(\mathrm{USD} / \mathrm{Wp})$ & Standoff Facade & Integrated Facade \\
\hline Modules & 3 & 3 \\
\hline BOS and installation & 1.11 & $(0.50)$ \\
\hline Central inverter and accessories & 1.71 & 1.71 \\
\hline Total & 5.83 & 4.21 \\
\hline
\end{tabular}

\section{Example: Reducing Cost through Integration}

An Australian commercial high-rise building demonstrated the substantial reductions in the cost of solar power generation through the use of a fully integrated design concept. The price of stand-alone grid-connected solar projects ranges from $\$ 0.70$ to $\$ 0.95 / \mathrm{kWh}$ (Australian). This commercial high-rise building realized enormous savings with the integrated design approach, generating solar electricity at $\$ 0.20-\$ 0.30 / \mathrm{kWh}$. Cost reductions of about $60 \%$ are attainable through smart integration of solar power systems. This system also produced an estimated operating cost saving of $\$ 214,000$ per annum and a return of $21.1 \%$ on a $\$ 1 \mathrm{M}$ additional capital investment in energy and water technologies. 


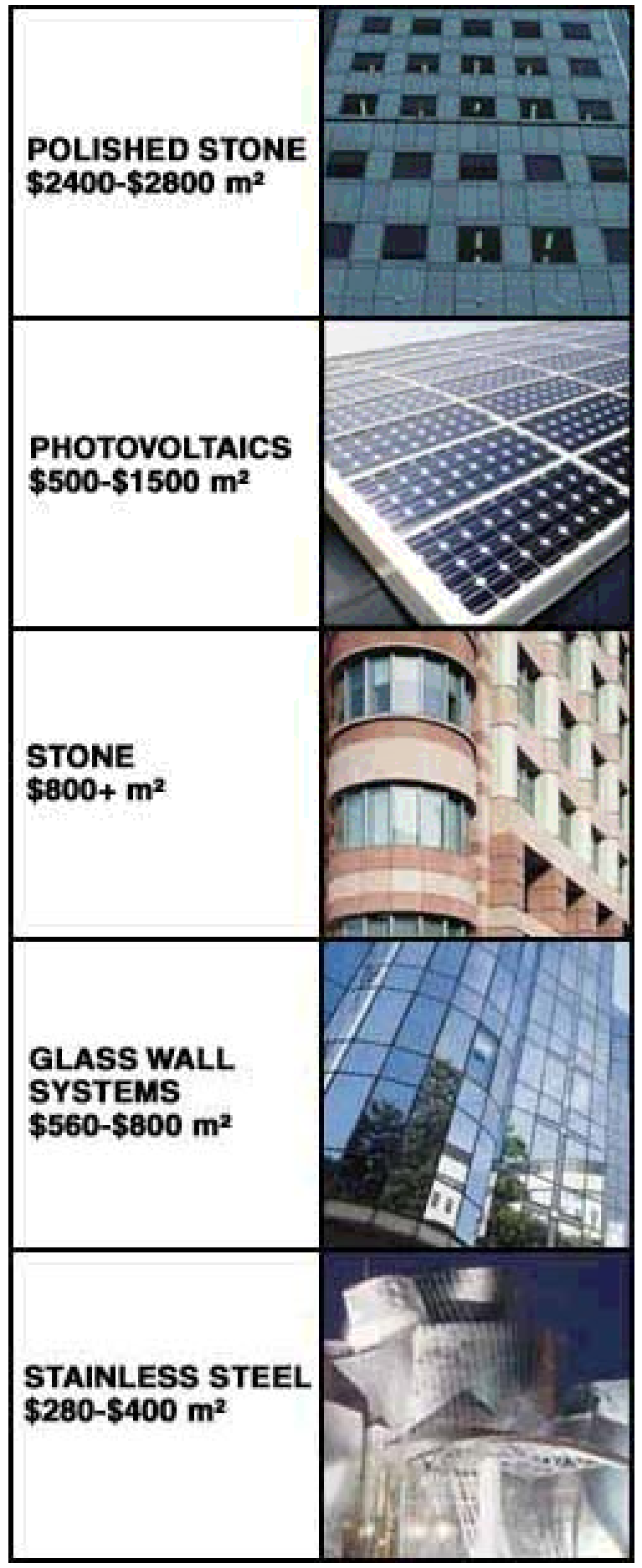

Figure 2: Reference costs of facade-cladding materials. 


\section{Labor Costs}

Because of low demand and low manufacturer production volumes in the United States, early BIPV system demonstration projects incurred high design and final product costs. The time and money required for the electrical and mechanical engineering and the installation methods have been relatively disproportionate to the total cost of the system (Kalin 1994). The standardization of BIPV building products and simplification of system engineering, design, and installation methods will most likely reduce labor costs of future BIPV systems.

Until BIPV becomes a mainstream technology, there will be a marginal added labor cost of architectural design, engineering design, and installation. However, with technical supervision, traditional building tradesmen (including glaziers, roofers, sheet metal workers, and electricians) can install BIPV systems. A manufacturer may supply the BIPV system to the technical supervisor, or a system integrator may be contracted separately. The cost of additional specialized technical supervision over traditional craftsmen should be included when a BIPV system is evaluated.

\section{Example: Reducing Cost of Installation}

The New Munich Trade Fair Center's 1-MW rooftop PV plant was built in a record time of 7 weeks. The key to the rapid installation of the 7,812 solar modules was the successful use of a new installation system with shockproof connectors. The solar modules that were manufactured in Munich were delivered to the installation site precabled, allowing for rapid installation and safe electrical connection.

\section{Maintenance Costs}

Maintenance costs can be significant in determining the long-term cost effectiveness of an investment. In lieu of including a major capital replacement as a standard item in the financial evaluation, the analysis may instead include maintenance costs deemed sufficient to keep the system operational over the time horizon of the decision-maker. Alternatively, system replacements may be included in the analysis. For the purpose of this guide, it is assumed that all repairs and replacements will be treated as part of maintenance costs. As with other costs, maintenance costs should be treated in terms of the added maintenance costs attributable to the BIPV system, rather than the total building maintenance costs. The BLCC model includes a provision for maintenance costs.

Manufacturers recommend periodic system checks and cleaning as part of a preventive maintenance routine. This includes regularly clearing away any debris and cleaning the PV surfaces exposed to the environment, which should be performed more often if the environment is particularly dirty. To determine the optimal cleaning schedule, the trade-off between the cost of cleaning the system to maximize power output and the value of the lost electricity without cleaning the system can be assessed. In some instances, particularly in high rises or buildings with unusual geometric shapes, cleaning the system can be more costly than the reduced power output. As a rule, visual inspection of essential components, based on an inspection checklist provided by the manufacturer, should be made every 6 months. Molenbroek et al. (2000) present some clever schemes to help PV system owners evaluate the performance of their systems. 
The utility meter and bill can be reviewed monthly to determine whether output from the system is dropping (adjusting for seasonal or other mitigating factors). Further investigation is warranted if this simple screening indicates poor system performance.

Annual detailed electronic testing is recommended. The string voltage can be tested with a voltmeter. (A string that shows low voltage relative to the others may have a faulty module or connector.) A data logbook should be maintained by the facility maintenance staff to record system performance, maintenance, and string voltage. Service adjustments and repair can be provided by the manufacturer, system integrator, distributor, or potentially by the utility company. For small, residential systems this might be quite costly, whereas for larger commercial building systems it might be very appropriate.

The labor costs for maintaining the system should be included in the economic analysis. Means Facility Construction Cost Data can be useful for estimating labor costs. Using the current Means Data, for example, will result in a salary of $\$ 26.60 / \mathrm{h}$ for a facility services engineer to maintain the system. The projected maintenance costs (assuming 8 hours per year) will be $\$ 212.80$ for a system smaller than $5 \mathrm{~kW}, \$ 425.60$ at 16 hours per year for a $5-100-\mathrm{kW}$ system, and $\$ 638.40$ at 24 hours per year for a system larger than $100 \mathrm{~kW}$. Some manufacturers offer complete turnkey systems, as well as optional service and maintenance contracts. Additionally, service contracts or personnel training and maintenance schedules can be negotiated as part of the project contract. Typically, training the facility engineer to service the system in-house will minimize the cost for system maintenance. Maintenance costs may comprise a routinely recurring part and a nonrecurring part, each of which can be separately included in the BLCC model.

\section{Example: Labor for Inspection and Replacement}

On the south facade of Energi's head office in Gothenburg, Sweden, is a $180 \mathrm{~m}^{2}$ Amorphous Thin Film integrated system. The 570 pieces of the $12-\mathrm{Wp}$ modules are mounted on specially designed aluminum profiles bolted to the facade. This technique allows for rapid installation and the possibility to remove individual modules for easy inspection and replacement.

\section{Example: Insurance Costs}

In Germany, housing insurance and electronic insurance are important. Housing insurance is required on the PV plant if the system is installed on the rooftop. Sometimes the insurance company increases the annual insurance rate; in other cases, companies include only the new equipment in the contract. Electronic insurance is needed to mitigate the risk to the plant operator in case of construction damage, operation damage, and environmental damages such as fire, lightning, or explosion. Usually replacement costs at current prices will be reimbursed. 


\section{Utility Interconnection Costs}

Utility interconnection costs are associated with the specific requirements determined by each state. State public utility companies have widely varying attitudes toward additional requirements, and their requirements vary. Costs can include large interconnection fees, net metering tariffs, metering calibration charges, engineering study fees, and standby charges. Additional requirements for liability insurance, property easement, legal indemnification, record keeping of all O\&M, and additional protection equipment will contribute to even greater utility interconnection costs. The relative cost of meeting these requirements is much greater for small systems than it is for larger systems. The cost of these requirements partly offsets the incentive provided by net metering and may deter customers - particularly small power customers-from participating.

A set of uniform interconnection standards can facilitate the implementation of net metering nationwide, and hopefully reduce this barrier to grid-connected BIPV. The renewable energy industry strives to work closely with utilities and standard-setting organizations in developing such standards.

\section{Example: Utility Interconnection Requirements for Professional Review Costs}

A homeowner in New Mexico recently asked his utility for the forms needed to interconnect his residential PV system and received a 36-page contract, not including the requisite exhibits. Faced with the prospect of hiring an attorney and a licensed engineer (for about 1,000 USD) to interconnect a 2-kW PV system, it is not surprising that homeowners like this one frequently abandon their projects.

The solution to the interconnection problem is uniform adherence to interconnection standards developed by recognized national authorities, including the National Electrical Code (NEC), Underwriter's Laboratories (UL), and the Institute of Electrical and Electronic Engineers (IEEE). Uniform adherence can happen through voluntary acceptance by utilities or by legislative or regulatory mandates (Starrs and Wenger 1998).

\section{Example: Property Tax}

In Alberta, Canada, a PV system almost attracted an additional $\$ 755$ annual property tax because it was exporting electricity across a property line. Any equipment that produces such electricity becomes "linear property" and is taxed at the municipality's mil rate (26.96 USD in 1996).

Another striking example of unexpected taxes occurred in Italy and Spain, where under original tax law, residential PV system owners were regarded as power producers by the tax department (Chivilet 2000). 


\section{Example: Fee for Grid Connection: Australia}

In Australia, the Mirvac Village Industry Consortium (MVIC) purchased several 1-kW PV systems to integrate into 630 houses. Each house has one meter to the grid and one from the grid, priced at $0.1015 \mathrm{AUS} / \mathrm{kWh}$ in each direction. Homeowners are charged a quarterly $\$ 15$ (\$9.6 USD) fee for grid connection.

\section{Costs Associated with Building Permits}

A building permit is required before any structure is built, added to, moved, or altered. Electrical permits are required for new, remodeled, or upgraded structures. The costs include fees for land disturbance, residential or commercial building permit fees, and re-inspection fees. Building permit fees may vary from county to county, state to state, and country to country. Generally, they are based on the estimated cost of construction or square footage. Therefore, permit fees may be increased by the addition of a BIPV system. Contact local land use and building design officials to identify specific project requirements. Only the added permit costs should be used in an economic analysis of a BIPV system.

Governmental Data Services, Inc. (GDS) provides software for complete contractor management, including entering building permits and calculating permit fees. Access to permits is given by address, legal description, owner name, water billing number, water meter serial number, or contact name.

\section{Example: Permit Fees}

\begin{tabular}{|l|l|}
\hline TOTAL VALUATION & FEE \\
\hline $0-3,000$ USD & 25.00 USD \\
\hline $3,001-50,000$ USD & $\begin{array}{l}25.00 \text { USD for the first 3,000 USD, plus } \\
6.00 \text { USD for each additional thousand or } \\
\text { fraction thereof, to and including 50,000 } \\
\text { USD }\end{array}$ \\
\hline $50,001-100,000$ USD & $\begin{array}{l}307.50 \text { USD for the first 50,000 USD, plus } \\
5.00 \text { USD for each additional thousand or } \\
\text { fraction thereof, to and including 100,000 } \\
\text { USD }\end{array}$ \\
\hline $100,001-500,000$ USD & $\begin{array}{l}557.00 \text { USD for the first 100,000 USD, } \\
\text { plus 4.00 USD for each additional } \\
\text { thousand or fraction thereof, to and } \\
\text { including 500,000 USD }\end{array}$ \\
\hline $500,001-$ more & $\begin{array}{l}2,157 \text { USD for the first 500,000 USD, plus } \\
3.00 \text { USD for each additional thousand or } \\
\text { fraction thereof }\end{array}$ \\
\hline
\end{tabular}

NOTE:

1. Construction cost estimated at $50 \mathrm{USD} / \mathrm{ft}^{2}$

2. Shell buildings' fees calculated at $80 \%$ of fee schedule

3. Certificate of occupancy at 10.00 USD each 


\section{Example: Building Permits in Canada}

The Edmonton Building Inspection Branch of Edmonton, Canada, required a residential building permit and a building development permit before a PV array weighing $300 \mathrm{~kg}$ and covering $21 \mathrm{~m}^{2}$ could be installed to ensure that roof loads and mechanical fastening standards were met. Sketches were submitted showing the PV module layout, and a photograph of the site had to be taken before the permits were granted (Howell and Eng 1999).

\section{Example: Building Permits in Germany}

In Germany, a homeowner can install a PV plant on the rooftop without a permit if the house is not classified as a national monument. The case is more complex if somebody rents a rooftop to install a PV plant. This renting procedure must be processed legally, and a contract between the homeowner and the person who is renting must be signed (Fraunhofer, ISE).

\section{Replacement and Repair Costs}

Generally, the life of the BIPV system is specified at 25 years, and it is presumed that none of the BIPV system subparts will require major replacement or repair during the study time frame, which is also often set equal to 25 years. (Minor repairs and small replacements needed to keep the system operational can be included in maintenance costs.) Of course, this is simply a modeling convention. In some instances, a part (likely the inverter) may require major replacement or repair sooner, and these costs can be included separately in the BLCC model.

\section{Salvage Value/Costs}

As another modeling convention, it is usually assumed at the end of the study period that no residual value or disposal costs remain for the BIPV system. Again, however, this convention may not fit the particular circumstances, and residual value and disposal costs can be explicitly estimated and included in the analysis. For example, an exception might arise if the BIPV system is composed of hazardous materials (associated with some thin-film PV technologies), which would require removal and generate significant disposal costs. Also, if batteries must be disposed of, there may be a salvage value or disposal cost depending on possible reuse value or cost of disposal. 


\section{Measurement and Verification for BIPV}

This section specifies M\&V for BIPV systems. Prescribing an internationally accepted guideline for $\mathrm{M} \& \mathrm{~V}$ can help to ensure that generation and savings requirements in BIPV systems will be accurately and consistently achieved.

\section{Protocol Background}

The International Performance Measurement \& Verification Protocol (IPMVP) was created in 1997 to increase reliability and savings, cut efficiency investment costs, and provide standardization required to secure lower-cost financing in energy and water efficiency projects. The Renewables Subcommittee, composed of leading international experts who share a goal of strengthening and fostering the rapid growth of renewable energy technologies, laid the groundwork for extending the success of the IPMVP to include renewable energy technologies. The Renewables Chapter provides an industry consensus framework to measure project benefits that are important to realizing the promise of renewable energy.

\section{Objectives}

$\mathrm{M} \& \mathrm{~V}$ may have several objectives from the earliest stage of renewable energy project development through the operation of the completed system:

- $\quad \mathrm{M} \& \mathrm{~V}$ can provide load profiles and information needed to establish project feasibility.

- $\mathrm{M} \& \mathrm{~V}$ can serve as a commissioning tool to confirm that systems were installed and are operating as intended.

- $\mathrm{M} \& \mathrm{~V}$ results may serve as the basis for payments to a financier over the term of a performance contract-an alternative financing mechanism in which an energy service company guarantees that after energy measures are installed at a facility, energy cost will be reduced. In many respects, the success of a performance contract project hinges on verifying that the energy cost savings closely match that which was guaranteed in the solicitation.

- Data gathered from an M\&V protocol can provide ongoing diagnostics and help sustain system performance and benefits over time.

- During financing contract development, a defined, accepted, and proven M\&V protocol helps increase customer comfort and reduce transaction costs by facilitating negotiations.

- Finally, an M\&V protocol is helpful to secure the full financial benefits of emissions reductions, such as emissions trading. To establish compliance with Emissions Reduction Targets, a regulating body must adopt a protocol for measuring emissions reductions.

$\mathrm{M} \& \mathrm{~V}$ should be scaled to the value of the project. The value of the information provided by a project's $M \& V$ procedures should be proportional to the value of the project. The objective is to minimize the combined total cost of the $\mathrm{M} \& \mathrm{~V}$ program plus the cost of uncertainty in the savings. The cost of uncertainty would most often be a higher interest rate. In general, the allowable relative error in an $\mathrm{M} \& \mathrm{~V}$ program will be negotiated between parties, with all parties trying to minimize total cost. As a rule, $\mathrm{M} \& \mathrm{~V}$ costs should fall within $3 \%-10 \%$ of typical project cost savings. 


\section{Options}

An M\&V program should be designed to measure and verify the specific performance claims of the deal or whatever the supplier claims to deliver. The M\&V options can be used individually or in combination, as complexity of performance and cost factors dictate. These options are not necessarily listed in increasing order of complexity or cost. For example, inspection can be more or less costly than metering, depending on the application. The four options follow:

Option A: Measured Capacity, Stipulated Performance-Engineering estimates based on system specifications are used to stipulate savings, and then the system is initially inspected to ensure that equipment was installed according to those specifications. The system is then periodically inspected to ensure that it is operating properly.

Option B: Measured Production/Consumption-Energy delivery over the term of a performance contract is directly measured by metering building output or indirectly measured by determining savings based on analysis of end-use electric or gas meters.

Option C: Utility Bill Analysis-Savings are inferred by the statistical analysis of whole-facility energy consumption without end-use metering of the system.

Option D: Calibrated Models-The long-term performance of a system is predicted by calibrating (renormalizing) a computer model based on data from a short-term test.

\section{Importance of Measurement and Verification}

Actual M\&V results based on IPMVP can prove success and provide developers, investors, lenders, and consumers with more confidence in the value of future projects. The IPMVP Renewables Subcommittee intends that the new chapter provide the renewable energy community with a valuable tool for implementing more renewable energy projects. As innovative renewable energy financing increases worldwide, so will the need for the IPMVP and its internationally standardized framework.

The IPMVP is available in a variety of formats at www.ipmvp.org/. 


\section{Evaluation}

As shown by the examples and the numerous variables influencing the economic assessment, the international BIPV market is diverse and rapidly developing. The examples show that niches on the market are under development.

The report reflects an extensive list of factors relevant for an economic analysis, so it can be used as a guideline to perform an economic analysis of BIPV systems. No general quantitative data could be presented of the costs and benefits of BIPV.

The outline and evaluation of the analytical investment methods showed their effectiveness for BIPV systems. All can be used to evaluate the BIPV economics in relation to other techniques. However, for designing and sizing BIPV systems, either NPV or LCC is recommended because BIPV tends to have increased net benefits and/or leads to reduced life cycle costs.

The criteria for the cost effectiveness depend on the investment decision maker. The most likely decision maker is the long-term owner-occupant, who is best positioned to reap the benefits of capital-intensive BIPV systems that have low operating costs.

The benefits of BIPV include multiple building functions; electricity benefits; grid-support benefits; control of load growth by utilities (institutionalized by utility and national incentives and programs); demand savings; power quality and reliability; promotional, educational, environmental, shading, and thermal benefits; and security.

The costs of BIPV depend on the system technology, utility interconnection costs, labor and installation costs, associated costs for building permits, maintenance costs, costs for replacement and repair, and the salvage costs (or value). 


\section{References \& Bibliography}

Byrne, J.; Letendre, S.; Wang, Y-D.; Nigro, R.; and Ferguson, W. (1997). "Building Load Analysis of Dispatchable Peak-Shaving Photovoltaic Systems: A Regional Analysis of Technical and Economic Potential." Proceedings of the American Solar Energy Society Conference, April. NREL/CP-520-23314. Boulder, CO: American Solar Energy Society.

Cadet Renewable Energy. Large Scale Photovoltaic-Integrated Roof at a Visitor Centre. Technical Brochure \#71. IEA/OECD.

California's Renewable Energy Buydown Program.

www.consumerenergycenter.org/buydown/program.html.

Chivilet, N.M. (2000). Presentation at Task 7 meeting in Stockholm.

Coles, L.; Packey, D.; Rau, N.; Wan, Y.H. (1995). Analysis of PV Benefit Case Studies: Results and Methods. Draft. Golden, CO: National Renewable Energy Laboratory.

Cost vs. Power-Electricity That Pays For Itself, While Helping to Protect The Environment. http://www.bpsolarex.com.

Currin Corporation. (September 1995). Title I, Phase I: Survey and Research, Addition of a Photovoltaic Energy Source to the Windigo Ranger Station Power System, Isle Royale National Park, Midland, MI. Midland, MI: Currin Corporation.

Currin Corporation. (September 1995). Title I, Phase I: Survey and Research, Addition of a Photovoltaic Energy Source for South Manitou Island, Sleeping Bear Dunes, Midland, MI. Midland, MI: Currin Corporation.

Dilger Metallbau GmbH—Schluchsee, Germany. www.nrel.gov/ncpv/documents/seb/seb12.html.

Duncan, T. (4 March 1997). Meeting Minutes. BLM Utah State Office, Denver, CO.

Eiffert, P. (September 1998). The Borrower's Guide to Financing Solar Energy Systems. NREL/BK-710-25104. Golden, CO: National Renewable Energy Laboratory.

Fact Sheet: New Munich Trade Fair Center. www.siemenssolar.com.

Fraunhofer, ISE. Economics and Financing of PV: The Situation in Germany.

Freedman, M. et al. (18 April 1995). Renewable Energy Sourcebook: A Primer for Action. Washington, DC: Public Citizen.

Green, H.J.; Wan, Y. (27 April-1 May 1998). "Current Experience with Net Metering Programs." Proceedings of Windpower '98. Washington, DC: American Wind Energy Association.

Hirshman, W. (January 2000). Going for the PV Gold at the Green Games. Photon. pp. 18-20. 
Howell, G.; Eng, P. (1999). Barriers to Utility Grid-Connected Solar Electric Power Systems-A Canadian Case Study. Edmonton, Alberta, Canada.

Hustedt, M. (2001). "The New German Renewable Energy Law (REL)." Member of the German Parliamant, Speaker of Bündnis 90/DIE GRÜNEN on Energy Policy.

International Energy Agency. (May 1996). Photovoltaic Power Systems in the Built Environment. Prepared for ENEL.

International Energy Agency. (11-12 February 1999). Photovoltaic Building Integration Concepts Workshop Proceedings. (http://www.task7.org/lausanne/procedings.pdf). p. 18.

Kalin, T.J. (11-15 April 1994). "PV as (a) New Architectural Element." Proceedings of the 12th European Photovoltaic Solar Energy Conference. Bedford, United Kingdom: H.S. Stephens and Associates; pp. 1847-1853.

Kiss, G.; Kinkead, J. (17-21 May 1993). "Building-Integrated Photovoltaics." Proceedings of the 3rd European Conference on Architecture. Felmersham, United Kingdom: H.S. Stephens and Associates; pp. 288-291.

Koner, P.K.; Dutta, V.; Chopra, K.L. (15 February 1999). A Comparative Life-Cycle Energy Cost Analysis of Photovoltaic and Fuel Generator for Load-Shedding Application. New Delhi 110016, India. Photovoltaic Laboratory, Centre for Energy Studies, Indian Institute of Technology.

Lepley, T.; Nath, P. (30 September-3 October 1997). "Photovoltaic Covered-Parking Systems Using Lightweight, Thin-Film PV." Prepared for the $26^{\text {th }}$ Photovoltaics Specialists Conference.

Molenbroek E.M. et al. (2000). "A simple tool for checking PV performance." $16^{\text {th }}$ European Photovoltaic Solar Energy Conference, 1-5 May 200, Glasgow, Scotland.

National Institute of Standards and Technology. (1995). LCC Program Version 4.21 Users Guide and Reference Manual. Gaithersburg, MD: National Institute of Standards and Technology.

National Institute of Standards and Technology. (October 1995). Energy Price Indices and Discount Factors for Life-Cycle Cost Analysis 1996. NISTIR 85-3273-10. Gaithersburg, MD: National Institute of Standards and Technology.

National Renewable Energy Laboratory. (1997). Cast Polycrystalline Silicon Photovoltaic Module Manufacturing Technology Improvements, Semiannual Technical Report. NREL/SR520-22503. Golden, CO: National Renewable Energy Laboratory.

Okotec Office Building, Berlin, Germany. www.nrel.gov/ncpv/documents/seb/seb11.html.

Posbic, J.; Rever, W. Economic Optimization of Building-integrated Photovoltaic Systems. www.bpsolarex.com.

Remote Power. www.nrel.gov/ncpv/documents/sweden.html. 
Renewable Energy Working Group. (1996). BLCC Preliminary Costing Guidelines for Renewable and Conventional Technologies. Draft. Washington DC: Federal Energy Management Program.

Ruegg, R.T.; Marshall, H.E. (1990). Building Economics: Theory and Practice. New York: Van Nostrand Reinhold.

Ruoss, D. (2000). A Green Pricing Model in Switzerland: The Solarstrom Stock Exchange from the Electricity Utility of the City of Zurich. The $2^{\text {nd }}$ World Solar Electric Buildings Conference: Sydney, 8-10 March 2000.

Schoen, T. (8-10 March 2000). BIPV Overview \& Getting PV into the Marketplace in the Netherlands. Sydney, Australia. The $2^{\text {nd }}$ World Solar Electric Buildings Conference, pp. 1-15.

Solarenergie-Forderverein. (5-9 December 1994). A New Path to Self-Sustaining Markets for PV. World Conference on Photovoltaic Energy Conversion. pp. 2357-2360.

Starrs, T. (27-30 June 1994). "Net Metering of Customer-Owned, Utility-Integrated Rooftop Photovoltaic Systems." Proceedings of the 1994 Annual Conference of the American Solar Energy Society, Boulder, CO: American Solar Energy Society; pp. 459-465.

Starrs, Thomas J. (19 March 1999). "Plugging into the Grid: Utility Interconnection of Net Metered Systems." Electric Revolution: New Electrical Technologies and What They Mean to You. Presentation. Portland, Oregon.

Starrs, T.; Wenger, H. (May/June 1998). "Net Metering and Small-Scale Renewables." Solar Today. (12:3), pp. 32-35.

Swezey, B.; Sinclair, K. (December 1992). Status Report on Renewable Energy in the States. TP462-5175. Golden, CO: National Renewable Energy Laboratory.

Urban Consortium Energy Task Force. (December 1995). PV Purchasing Guidebook for Local and State Government. Washington, DC: Public Technologies, Inc., p. 4.

Walker, H.A.; Eiffert Taylor, P.; Hayter, S.J.; Maytum, M.; Christensen, J.; Coonen, S.; Rever, W.B. III; Vanderhoff, S. (1997). Building-Integrated Photovoltaic System: The Thoreau Center for Sustainability. Boulder, CO: American Solar Energy Society.

Wan, Y. (December 1996). Net Metering Programs. SP-460-21651. Golden, CO: National Renewable Energy Laboratory.

Watt, M.; Outhred, H. (8-10 March 2000). Financing Strategies and Market TransformationOptions and Issues. Sydney, Australia. The $2^{\text {nd }}$ World Solar Electric Buildings Conference, pp. 99-103.

Wenger, H.; Eiffert, P. (1996) The Architect's Perspective on the Use of PV in Buildings: Questionnaire Results. Building Energy Proceedings, $1^{\text {st }}$ Solar Electric Building Conference, Boston, MA. 
Wenger H.J.; Hoff, T.E.; Farmer, B.K. "Measuring the Value of Distributed Photovoltaic Generation: Final Results of the Kerman Grid-Support Project," First World Conference on Photovoltaic Energy Conversion (Waikoloa, HI, December 1994).

West, R.E.; Kereith, F. (1988). Economic Analysis of Solar Thermal Energy Systems. Cambridge, MA: Massachusetts Institute of Technology Press. 435 pp.

Wilk, H. et al. (2001). Innovative electrical concepts, report prepared within IEA PVPS Task 7.

Wohlgemuth, J. (10 May 1996). Interview with author. Solarex, Frederick, MD.

Wren, C.; Barram, F. (8-10 March 2000). Solar Integration on Commercial Buildings. Sydney, Australia. The $2^{\text {nd }}$ World Solar Electric Buildings Conference, pp. 68-74.

Yoo, S.H.; Lee, E.T.; Lee, J.K. (1998). Building-Integrated Photovoltaics: A Korean Case Study. 1998 Elsevier Science, Ltd. Printed in Great Britain. Solar Energy Vol. 64, Nos. 4-6, pp. 151-161. 


\section{Appendix A: Acronyms and Abbreviations}

\begin{tabular}{|c|c|}
\hline AEG & Applied Energy Group \\
\hline AIRR & adjusted internal rate of return \\
\hline BIPV & building-integrated photovoltaics \\
\hline BLCC & building life cycle costs \\
\hline BLM & Bureau of Land Management (USA) \\
\hline BOS & balance of system \\
\hline CEEP & Center for Energy and Environmental Policy \\
\hline $\mathrm{CO}_{2}$ & carbon dioxide \\
\hline DOE & U.S. Department of Energy \\
\hline DOI & U.S. Department of Interior \\
\hline DM & deutsche mark \\
\hline DSIRE & National Database of State Incentives for Renewable Energy (USA) \\
\hline DSM & demand-side management \\
\hline EPA & U.S. Environmental Protection Agency \\
\hline EREC & Efficiency and Renewable Energy Clearinghouse \\
\hline ESCO & Energy Service Company \\
\hline FEMP & Federal Energy Management Program (USA) \\
\hline GDS & Governmental Data Services (USA) \\
\hline IEA & International Energy Agency \\
\hline IEEE & Institute of Electrical and Electronic Engineers \\
\hline IPMVP & International Performance Measurement and Verification Protocol \\
\hline IREC & Interstate Renewable Energy Council (USA) \\
\hline IRR & internal rate of return \\
\hline $\mathrm{kg}$ & kilograms \\
\hline kWh & kilowatt-hour \\
\hline KWp & kilowatts peak \\
\hline LCC & life cycle cost \\
\hline$M \& V$ & measurement and verification \\
\hline MARR & minimum acceptable rate of return \\
\hline MVIC & Mirac Village Industry Consortium (Australia) \\
\hline MWh & megawatts per hour \\
\hline MWp & megawatts peak \\
\hline NB & net benefits \\
\hline NCPV & National Center for Photovoltaics (USA) \\
\hline NEC & National Electric Code (USA) \\
\hline NIST & National Institute for Standards and Technology (USA) \\
\hline $\mathrm{NO}_{x}$ & nitrogen oxide \\
\hline NPS & National Park Service (USA) \\
\hline NPV & net present value \\
\hline NREL & National Renewable Energy Laboratory (USA) \\
\hline O\&M & operations and maintenance \\
\hline OSHA & Occupational Safety and Health Administration (USA) \\
\hline PUCs & public utility commissions \\
\hline RWG & Renewable Working Group \\
\hline SIR & saving to investment ratio \\
\hline $\mathrm{SO}_{2}$ & sulfur dioxide \\
\hline TMY & typical meteorological year \\
\hline UL & Underwriter's Laboratory (USA) \\
\hline UPS & uninterruptible power supply \\
\hline UPVG & Utility Photovoltaic Group \\
\hline USD & United States dollars \\
\hline U.S. State Department & U.S. Department of State \\
\hline Wp & watts peak \\
\hline
\end{tabular}




\section{Appendix B: Glossary}

Balance of system (BOS): A term used to refer to components other than modules. BOS includes the power conditioning equipment (inverter and rectifier), array foundation, support structure, sun-trackers (optional), backup power (usually a battery bank), wiring, and electrical system protection devices.

Break-even analysis: A technique for dealing with uncertainty in cost and benefit estimates, which entails determining the minimum or maximum value that a variable can have and still result in a project whose present value benefits (savings) will just cover its costs. (Note: The time to payback is a measure of break-even life.)

Cost of capital: The rate of return on the next best available use of investment funds. An investor typically uses this rate to establish the minimum acceptable rate of return (MARR).

Energy savings performance contracting (ESPC): Authorized by the Energy Policy Act of 1992 (EPAct), the ESPC option allows energy service companies to assume the capital costs of installing energy and water conservation equipment and renewable energy systems. In the ESPC process, the energy service company guarantees a fixed amount of energy cost savings throughout the life of the contract (up to 25 years) and is paid directly from those cost savings. Agencies retain the remainder of the energy cost savings. (Energy cost savings refers to any reduction in utilities at a federal building.)

First-cost approach: Selecting among alternatives based on which has the lowest up-front costs.

Life cycle cost (LCC): The sum of time-equivalent costs of acquiring, owning, operating, and maintaining a building, system, or equipment over a designated study period. Comparing LCCs of alternative building designs, systems, or equipment that equally satisfy functional requirements is one way of choosing among them on economic grounds.

Low-E (low-emittance) coating or glazing: Microscopically thin and virtually invisible metal or metallic oxide layers deposited on a window or skylight glazing surface, primarily to reduce the U-factor by suppressing radiative heat flow. A typical type of low-E coating is transparent to the solar spectrum (visible light and short-wave infrared radiation) and reflective of long-wave infrared radiation.

Marginal (or added) cost: The difference between the total building system cost with and without the added photovoltaic system.

Marginal cost of capital: The rate of return on the next-best available use of investment funds. An investor typically uses this rate to establish the discount rate and the minimum acceptable rate of return (MARR).

Minimum acceptable rate of return (MARR): The minimum percentage return required for an investment to be economically acceptable.

Net benefit analysis: The net difference between two (energy) systems, taking into account the relative benefits and costs, expressed in present or annual value dollars.

Payback after taxes: This includes and evaluates marginal tax rates and depreciation schedules. 
Payback period: The minimum time it takes to recover an investment. The "simple payback period" for an energy system is the total investment cost divided by the first year's revenues from energy saved, displaced, or produced.

Savings-to-investment (or benefit-to-cost) ratio: A ratio of savings to costs, or benefits to costs, for one building design, system, equipment, or strategy versus an alternative.

Time-value of money: The time-dependent value of money arising from price inflation/deflation and from its earning potential over time. 


\section{Appendix C: Methods of Assessing Capital Budget Decisions}

Methods of Financial Analysis

\begin{tabular}{|c|c|c|c|c|}
\hline Financial Analysis Method & $\begin{array}{l}\text { General Formulas (all costs expressed } \\
\text { as present value) }\end{array}$ & Selection Criteria & Benefits & Disadvantages \\
\hline $\begin{array}{l}\text { Net Benefit (NB) Analysis } \\
\text { (B-C) } \\
\text { Benefits net of costs } \\
\text { expressed as an initial } \\
\text { lump-sum amount }\end{array}$ & $\begin{array}{l}(\mathbf{B}-\mathbf{C})=\mathbf{E}-(\mathbf{P}-\mathbf{S}+\mathbf{M}+\mathbf{R}) \\
\mathrm{E}=\text { reduction in electricity costs } \\
\mathrm{P}=\text { differential purchase and installation } \\
\text { costs } \\
\mathrm{S}=\text { differential salvage value } \\
\mathrm{M}=\text { differential maintenance and repair } \\
\text { costs } \\
\mathrm{R}=\text { differential replacement costs }\end{array}$ & $\mathrm{NB}>0$ & $\begin{array}{l}\text { a) Useful when there are } \\
\text { multiple kinds of benefits } \\
\text { and not just cost avoidance } \\
\text { b) Provides long-term } \\
\text { evaluation of system } \\
\text { performance } \\
\text { c) Good for designing and } \\
\text { sizing systems }\end{array}$ & $\begin{array}{l}\text { Not always reliable for } \\
\text { comparing one investment } \\
\text { opportunity with other non- } \\
\text { mutually exclusive } \\
\text { opportunities }\end{array}$ \\
\hline $\begin{array}{l}\text { Savings-to-Investment } \\
\text { Ratio (SIR) } \\
\text { Numerical ratio that } \\
\text { represents how many times } \\
\text { savings exceed costs, over } \\
\text { and above compensating for } \\
\text { the time value of money }\end{array}$ & $\begin{array}{l}\mathbf{S I R}=\underline{(\mathbf{E}-\mathbf{M})} \\
\mathrm{E}=\text { reduction in electricity costs } \\
\mathrm{M}=\text { differential maintenance and repair } \\
\text { costs } \\
\mathrm{P}=\text { differential purchase and installation } \\
\text { costs } \\
\mathrm{S}=\text { differential salvage value } \\
\mathrm{R}=\text { differential replacement costs }\end{array}$ & $\mathrm{SIR}>1$ & $\begin{array}{l}\text { a) Can be used to determine } \\
\text { the cost-effectiveness of a } \\
\text { project } \\
\text { b) Can be used to rank } \\
\text { projects when there is a } \\
\text { limited budget }\end{array}$ & $\begin{array}{l}\text { a) Ratio may change } \\
\text { depending on which } \\
\text { amounts are placed in the } \\
\text { numerator or } \\
\text { denominator } \\
\text { b) Does not directly show } \\
\text { magnitude of net savings } \\
\text { in monetary terms }\end{array}$ \\
\hline
\end{tabular}




\begin{tabular}{|c|c|c|c|c|}
\hline Financial Analysis Method & $\begin{array}{l}\text { General Formulas (all costs expressed } \\
\text { as present value) }\end{array}$ & Selection Criteria & Benefits & Disadvantages \\
\hline $\begin{array}{l}\text { Life Cycle Cost (LCC) } \\
\text { Present value sum of costs } \\
\text { and benefits over the life of a } \\
\text { system }\end{array}$ & $\begin{array}{l}\mathbf{L C C}=\mathbf{P}-\mathbf{S}+\mathbf{M}+\mathbf{R}+\mathbf{E} \\
\mathrm{P}=\text { purchase and installation costs } \\
\mathrm{S}=\text { salvage value } \\
\mathrm{M}=\text { maintenance and repair costs } \\
\mathrm{R}=\text { replacement costs } \\
\mathrm{E}=\text { electricity costs }\end{array}$ & $\begin{array}{l}\text { Compare LCC } \\
\text { among mutually } \\
\text { exclusive } \\
\text { alternatives } \\
\text { Minimum LCC } \\
\text { LCC1 < LCC2 }\end{array}$ & $\begin{array}{l}\text { a) Cost-effective measure } \\
\text { b) Can be used to design or } \\
\text { size a system in which costs } \\
\text { predominate } \\
\text { c) Best for cost-focused } \\
\text { decisions } \\
\text { d) Can be used for qualitative } \\
\text { trade-off analysis (e.g., Is } \\
\text { increasing LCC by a } \\
\text { certain amount worth } \\
\text { gaining a certain quantity } \\
\text { of avoided emissions?) } \\
\text { e) Comparison of two } \\
\text { alternative LCCs yields net } \\
\text { savings of the low relative } \\
\text { to the high }\end{array}$ & $\begin{array}{l}\text { Not sufficient for ranking } \\
\text { among projects when there } \\
\text { is a budget constraint }\end{array}$ \\
\hline
\end{tabular}




\section{REPORT DOCUMENTATION PAGE}

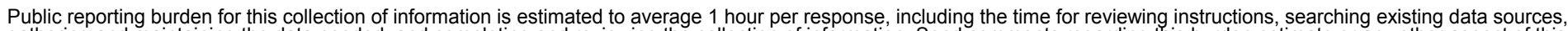

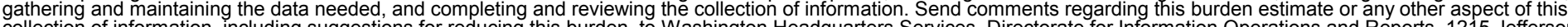
Davis Highway, Suite 1204, Arlington, VA 22202-4302, and to the Office of Management and Budget, Paperwork Reduction Project (0704-0188), Washington, DC 20503.

\begin{tabular}{|l|l|l|}
\hline 1. AGENCY USE ONLY (Leave blank) & $\begin{array}{l}\text { 2. REPORT DATE } \\
\text { January } 2003\end{array}$ & $\begin{array}{l}\text { 3. REPORT TYPE AND DATES COVERED } \\
\text { Technical Report }\end{array}$ \\
\hline
\end{tabular}

\section{TITLE AND SUBTITLE}

Guidelines for the Economic Evaluation of Building-Integrated Photovoltaic Power Systems

6. $\operatorname{AUTHOR}(\mathrm{S})$

P. Eiffert and the International Energy Agency (IEA) PVPS Task 7

7. PERFORMING ORGANIZATION NAME(S) AND ADDRESS(ES)

National Renewable Energy Laboratory

1617 Cole Blvd.

Golden, CO 80401-3393

9. SPONSORING/MONITORING AGENCY NAME(S) AND ADDRESS(ES)
5. FUNDING NUMBERS

PVP2.8201

8. PERFORMING ORGANIZATION REPORT NUMBER

NREL/TP-550-31977

10. SPONSORING/MONITORING AGENCY REPORT NUMBER

11. SUPPLEMENTARY NOTES

12a. DISTRIBUTION/AVAILABILITY STATEMENT

National Technical Information Service

12b. DISTRIBUTION CODE

U.S. Department of Commerce

5285 Port Royal Road

Springfield, VA 22161

13. ABSTRACT (Maximum 200 words)

This report identifies the economic parameters of building-integrated PV (BIPV) systems. The guidelines are structured in three major parts: the investment analysis (methods and ownership issues), benefits, and costs. Measurement and verification are also discussed briefly.

The outline and evaluation of investment analysis methods showed their effectiveness for BIPV systems. All investment methods can be used to evaluate BIPV economics (in relation to other techniques). However, for designing and sizing BIPV systems, either net present value or life cycle cost is recommended.

The advantages of BIPV systems include multiple (building) functions, electricity benefits, grid-support benefits, control of load growth by utilities (institutionalized by utility and national incentives and programs), demand savings, power quality and reliability, promotional and educational benefits, environmental benefits, shading and thermal benefits, and security. Each topic is addressed, and international examples are given for most.

The costs of BIPV systems depend on the system technology, utility interconnection costs, labor and installation costs, associated costs for building permits, maintenance costs, costs for replacement and repair, and the salvage costs (or value). Each topic is addressed, and international examples are given for most.

photovoltaics; building-integrated PV systems; BIPV systems

15. NUMBER OF PAGES

14. SUBJECT TERMS

16. PRICE CODE

17. SECURITY CLASSIFICATION OF REPORT Unclassified
18. SECURITY CLASSIFICATION OF THIS PAGE Unclassified
19. SECURITY CLASSIFICATION OF ABSTRACT

Unclassified
20. LIMITATION OF ABSTRACT

UL 